\title{
A Review of Enzyme Induced Carbonate Precipitation (EICP): The Role of Enzyme Kinetics
}

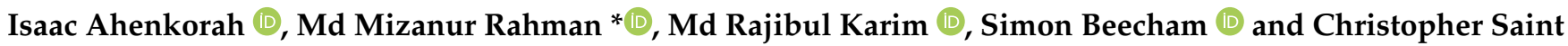

UniSA STEM, University of South Australia, Mawson Lakes, SA 5095, Australia; isaac.ahenkorah@mymail.unisa.edu.au (I.A.); rajibul.karim@unisa.edu.au (M.R.K.); simon.beecham@unisa.edu.au (S.B.); christopher.saint@unisa.edu.au (C.S.)

* Correspondence: mizanur.rahman@unisa.edu.au

Citation: Ahenkorah, I.; Rahman, M.M.; Karim, M.R.; Beecham, S.; Saint, C. A Review of Enzyme Induced Carbonate Precipitation (EICP): The Role of Enzyme Kinetics. Sustain. Chem. 2021, 2, 92-114. https://doi.org/10.3390/ suschem 2010007

Received: 20 December 2020

Accepted: 10 February 2021

Published: 22 February 2021

Publisher's Note: MDPI stays neutra with regard to jurisdictional claims in published maps and institutional affiliations.

Copyright: (c) 2021 by the authors. Licensee MDPI, Basel, Switzerland. This article is an open access article distributed under the terms and conditions of the Creative Commons Attribution (CC BY) license (https:/ / creativecommons.org/licenses/by/ $4.0 /)$.
Abstract: Enzyme-induced carbonate precipitation (EICP) is a relatively new bio-cementation technique for ground improvement. In EICP, calcium carbonate $\left(\mathrm{CaCO}_{3}\right)$ precipitation occurs via urea hydrolysis catalysed by the urease enzyme sourced from plants. EICP offers significant potential for innovative and sustainable engineering applications, including strengthening of soils, remediation of contaminants, enhancement of oil recovery through bio-plugging and other in situ field applications. Given the numerous potential applications of EICP, theoretical understanding of the rate and quantity of $\mathrm{CaCO}_{3}$ precipitation via the ureolytic chemical reaction is vital for optimising the process. For instance, in a typical EICP process, the rate and quantity of $\mathrm{CaCO}_{3}$ precipitation can depend significantly on the concentration, activity and kinetic properties of the enzyme used along with the reaction environment such as $\mathrm{pH}$ and temperature. This paper reviews the research and development of enzyme-catalysed reactions and its applications for enhancing $\mathrm{CaCO}_{3}$ precipitation in EICP. The paper also presents the assessment and estimation of kinetic parameters, such as the maximal reaction velocity $\left(\mathrm{V}_{\max }\right)$ and the Michaelis constant $\left(\mathrm{K}_{\mathrm{m}}\right)$, that are associated with applications in civil and geotechnical engineering. Various models for evaluating the kinetic reactions in EICP are presented and discussed, taking into account the influence of $\mathrm{pH}$, temperature and inhibitors. It is shown that a good understanding of the kinetic properties of the urease enzyme can be useful in the development, optimisation and prediction of the rate of $\mathrm{CaCO}_{3}$ precipitation in EICP.

Keywords: urease enzyme; urea hydrolysis; bio-cementation; EICP; enzyme kinetics

\section{Introduction}

Enzyme induced carbonate precipitation (EICP) is an innovative ground improvement technique that involves calcium carbonate $\left(\mathrm{CaCO}_{3}\right)$ precipitation via the hydrolysis of urea $\left(\mathrm{CO}\left(\mathrm{NH}_{2}\right)_{2}\right)$ into ammonium $\left(\mathrm{NH}_{4}^{+}\right)$and carbonate $\left(\mathrm{CO}_{3}^{2-}\right)$ ions catalysed by the urease enzyme. The EICP process has the potential to be applied as bio-cementation and bio-remediation solutions in many environmental, construction, geotechnical and civil engineering problems, such as improving soil strength, reducing soil liquefaction potential, surface erosion control, reducing permeability, heavy metal contaminant remediation and so forth [1-5]. One advantage of EICP is the smaller size of the urease enzyme crystals (typically $12 \mathrm{~nm}$ or $120 \AA$ ), rendering the process effective for a wider range of soils, including fine-grained soils [6]. However, the cost of EICP treatment can be high. Pure urease enzyme is the most expensive component ( $70 \%$ to $80 \%$ of the total cost) of the chemical ingredients used. Although some studies have used crude urease extract as a costeffective source of enzyme, some extraction techniques may require additional processes or chemicals and may sometimes yield only a small quantity of urease enzyme. Other drawbacks of the EICP process can be the lack of nucleation sites, meaning that a portion of $\mathrm{CaCO}_{3}$ is precipitated in the pore spaces, which may remain ineffective in binding soil particles. Hence, a sustainable adaptation of EICP as a bio-cementation technique depends 
on the optimisation of chemical ingredients and curing time (reaction/precipitation time) to reduce construction cost and time.

The catalytic actions of enzymes speed up the process of urea hydrolysis by a factor of millions compared to the rate of an uncatalyzed reaction [7-9]. The concentration and activity of the urease enzyme dictate the catalytic mechanism and thus the reaction/precipitation rate. Accordingly, the theoretical understanding of enzyme kinetics is important for controlling and predicting the rate of $\mathrm{CaCO}_{3}$ precipitation. Hence, the catalytic mechanism, structure, function and kinetic properties of the urease enzyme has been a subject of extensive research.

The quantitative description of enzymatic reactions was first proposed by Michaelis and Menten [10]. Their model provides a theoretical understanding of the rate of product formation as well as methods for estimating the kinetic parameters [11,12]. The urea hydrolysis process is often constrained by several factors including the concentration of the substrate, temperature, $\mathrm{pH}$ and the presence of inhibitors $[1,13,14]$. This results in a limited operational lifetime of enzymes and difficulty in understanding the mechanisms of an enzyme-catalysed reaction $[15,16]$. A comprehensive understanding of enzyme kinetics may be useful for accurate monitoring, prediction and controlling of $\mathrm{CaCO}_{3}$ precipitation rates. This may result in a significant reduction in costs, yield less undesirable by-products and a shorter treatment duration for practical engineering applications [1], however, neither theoretical nor empirical approaches to controlling the curing time have been reported in the literature.

The lack of consideration of enzyme kinetics in many recent EICP studies has resulted in several discrepancies in the reported optimum concentration of chemical constituents such as urea, calcium chloride and urease enzyme. A comprehensive study by Ahenkorah, Rahman [17] revealed that the current knowledge of optimisation is based on trial and error, which has led to inconsistent optimum concentrations of chemical ingredients reported in different studies [5,17-19]. For example, Hamdan [5] reported an optimum urea- $\mathrm{CaCl}_{2}$ concentration ratio of $1.75: 1(\mathrm{M})$ for $0.47 \mathrm{~g} / \mathrm{L}$ of urease enzyme, while Almajed, Khodadadi Tirkolaei [19] found that a urea- $\mathrm{CaCl}_{2}$ concentration ratio of 1:0.67 (M) for $3 \mathrm{~g} / \mathrm{L}$ urease enzyme was optimum. Neupane, Yasuhara [18] treated an equimolar urea- $\mathrm{CaCl}_{2}$ concentration of $0.5 \mathrm{M}$ with $2 \mathrm{~g} / \mathrm{L}$ urease enzyme and Putra, Yasuhara [20] reported an equimolar concentration of $0.5 \mathrm{M}$ of urea-CaCl${ }_{2}$ for $1 \mathrm{~g} / \mathrm{L}$ urease enzyme to be optimum. Carmona, Oliveira [21] considered urease enzyme activity and treated an equimolar concentration of $0.25 \mathrm{M}$ of urea- $\mathrm{CaCl}_{2}$ with $4 \mathrm{kU} / \mathrm{L}$ urease enzyme as optimum. The differences in these studies can be explained by the differences in the urease enzyme concentration $(\mathrm{g} / \mathrm{L})$, its activity $(\mathrm{U} / \mathrm{g})$, catalytic properties and can also be affected by other factors including temperature, $\mathrm{pH}$ and the presence of inhibitors, which can be captured in a single framework using knowledge from existing kinetic models [10].

Thus, a thorough understanding of enzyme kinetics, which dictates the urea hydrolysis rate that is proportional to the rate of $\mathrm{CaCO}_{3}$ precipitation in ideal conditions is required for developing an effective framework for $\mathrm{CaCO}_{3}$ precipitation in EICP. This article offers a comprehensive review of the properties, molecular structure and kinetic mechanisms of urease enzymes. Further, various models for quantifying the kinetic reactions in EICP are presented and discussed, taking into account the influence of $\mathrm{pH}$, temperature and inhibitors.

\section{Biogeochemical Reactions in EICP}

\subsection{Molecular Structure of Urease Enzyme}

Urease enzyme is a nickel-containing metalloenzyme synthesized by some plants, bacteria and fungi [22]. Ureases belong to the superfamily of amidohydrolases and phosphotriesterases, which display catalytic mechanisms in their active sites. In general, ureases contain two $\mathrm{Ni}^{2+}$ ions in their active sites. It has been well-established in the literature that the overall protein scaffold is conserved among ureases from different sources [23]. Urease enzymes in plants and fungi generally consist of homo-oligomeric proteins with identical sub-units compared to the multimeric proteins found in bacterial ureases which are formed 
from a complex of two $(\alpha \beta)$ or three $(\alpha \beta \gamma)$ subunits [24]. These proteins appear to act as urease-specific chaperones required for assembling an active urease [25-27].

From the literature, the most extensively studied urease enzymes are sourced from Jack bean $[28,29]$. Other plant species rich in urease include Weeping bottlebrush (Callistemon viminalis), Mulberry (Morus alba), Palo verde (Parkinsonia florida), Pigweed (Chenopodium album), Pigeonpea (Cajanus cajan), Bitter melon seeds (Momordica charantia), Squash seeds (Cucurbitaceae), Soybean (Glycine max), Sword beans (Canavalia gladiata), Watermelon seeds (Citrullus lanatus), Cabbage leaves and Soy pulp [6,30].

In this study, the crystal and molecular structure of urease sourced from Jack bean are investigated. The Jack bean was selected as it is one of the most common sources of urease used in many different studies of the EICP process. Jack bean urease complex with phosphate (PDB: 3LA4) was extracted from the Protein Data Bank (PDB) using the University of California San Francisco (UCSF) Chimera software [31,32]. Figure 1 shows the structural components of the Jack bean urease enzyme, which consists of the N-terminal, C-terminal and $\alpha-\beta$ domains. The C-terminal $(\alpha \beta)$ triose-phosphate isomerase (TIM) barrel domain contains the active site which controls the activity of the enzyme. This activity is largely controlled by the presence of a binuclear Ni complex active site in the $\beta$-sheet structure and the dynamic opening and closing of the mobile flap located adjacent to the active site [32-36]. Higher availability of the active site can be achieved during the wider opening of the mobile flap and can result in higher activity [35,37]. The functional unit of ureases from plants is made of six identical subunits, called $\alpha$ subunits, each of which are reported to have a molecular weight of around $90 \mathrm{kDa}$, making the total molecular weight of a subunit approximately $540 \mathrm{kDa}[38,39]$.

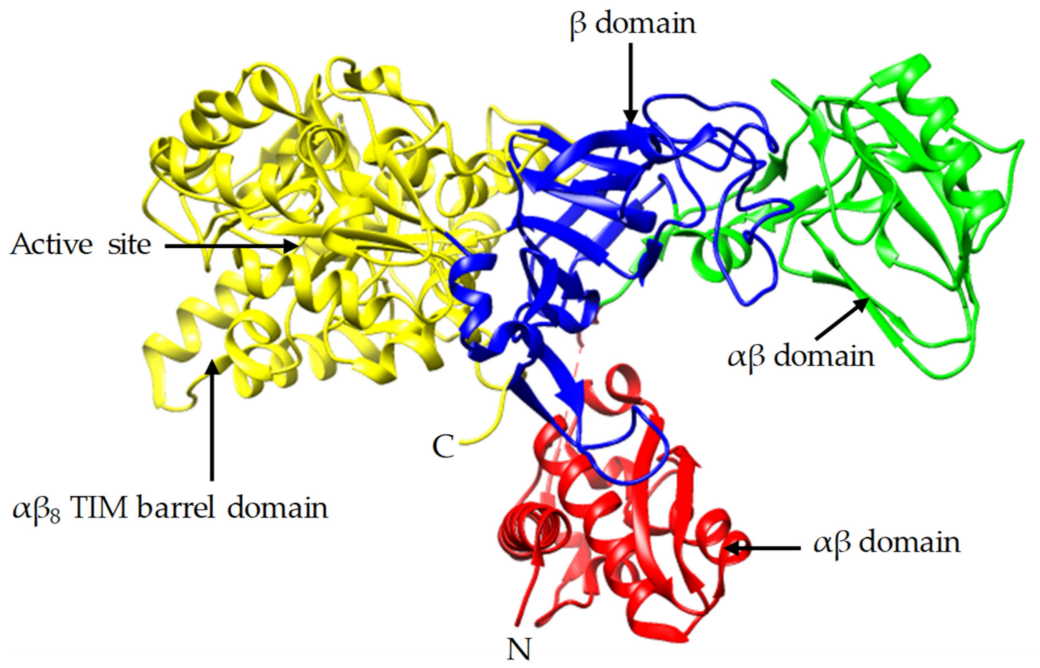

Figure 1. Crystal structure of Jack bean urease (PDB: 3LA4).

\subsection{Urease Catalysed Chemical Reactions}

The major chemical constituents involved in the EICP process are urease enzyme, urea $\left(\mathrm{CO}\left(\mathrm{NH}_{2}\right)_{2}\right)$ and calcium chloride $\left(\mathrm{CaCl}_{2}\right)$. The chemical reactions involved are presented in Equations (1)-(5) [40].

$$
\begin{gathered}
\mathrm{CO}\left(\mathrm{NH}_{2}\right)_{2(\mathrm{~s})}+\mathrm{H}_{2} \mathrm{O}_{(\mathrm{l})} \stackrel{\text { urease enzyme }}{\rightarrow} \mathrm{NH}_{3(\mathrm{aq})}+\mathrm{CO}\left(\mathrm{NH}_{2}\right) \mathrm{OH}_{(\mathrm{aq})} \\
\mathrm{CO}\left(\mathrm{NH}_{2}\right) \mathrm{OH}_{(\mathrm{aq})}+\mathrm{OH}^{-}{ }_{(\mathrm{aq})} \rightarrow \mathrm{NH}_{3(\mathrm{aq})}+\mathrm{HCO}_{3(\mathrm{aq})}^{-} \\
\mathrm{NH}_{3(\mathrm{aq})}+\mathrm{HCO}_{3(\mathrm{aq})}^{-} \rightarrow \mathrm{NH}_{4(\mathrm{aq})}^{+}+\mathrm{CO}_{3(\mathrm{aq})}^{2-} \\
\mathrm{CaCl}_{2(\mathrm{~s})} \stackrel{\mathrm{H}_{2} \mathrm{O}}{\rightarrow} \mathrm{Ca}^{2+}{ }_{(\mathrm{aq})}+2 \mathrm{Cl}^{-}{ }_{(\mathrm{aq})}
\end{gathered}
$$




$$
\mathrm{Ca}^{2+}(\mathrm{aq})+\mathrm{CO}_{3(\mathrm{aq})}^{2-} \stackrel{\text { precipitation }}{\leftrightarrow} \mathrm{CaCO}_{3(\mathrm{~s})}
$$

The chemical reaction which occurs during urea hydrolysis brings about primary geochemical changes, such as an increase in $\mathrm{pH}$ and inorganic carbon (Equations (1)-(3)). The geochemical changes in the EICP process are dynamic and dependent on the ratios and concentration of the chemical constituents used. For example, the precipitation of $\mathrm{CaCO}_{3}$ occurs in the presence of $\mathrm{Ca}^{2+}$, which shifts the carbonate equilibrium reaction from $\mathrm{CO}_{2}$ to $\mathrm{HCO}_{3}^{-}$to $\mathrm{CO}_{3}^{2-}$ in a suitable alkaline environment ( $\mathrm{pH} 8.0$ to 9.0) [5].

The use of non-equimolar quantities of urea and $\mathrm{CaCl}_{2}$ may result in an increase or decrease in ammonia $\left(\mathrm{NH}_{3}\right)$ release which affects the alkalinity $(\mathrm{pH})$ of the chemical environment [5]. For example, a high urea concentration may result in an increase in alkalinity due to the abundance of $\mathrm{NH}_{3}$ in the absence of $\mathrm{Ca}^{2+}$. Hence, $\mathrm{Ca}^{2+}$ becomes the limiting reagent in the reaction [5]. In contrast, there may be a reduction in alkalinity with high $\mathrm{CaCl}_{2}$ concentration and there may be an excess of $\mathrm{Ca}^{2+}$ available in the system with a limited amount of carbonate ions [5].

It has been reported in the literature that the presence of the urease enzyme accelerates the urea hydrolysis and reaction speed up to $10^{14}$ times compared to the rate of the uncatalyzed reaction $[5,41]$. The activity of the urease enzyme is usually expressed in Units $(\mathrm{U})$, defined as the amount of enzyme required to hydrolyse $1 \mu \mathrm{mol}$ urea per minute at a $\mathrm{pH}$ of 7.0 and at a temperature of $25^{\circ} \mathrm{C}$ to produce $\mathrm{NH}_{3}$ and $\mathrm{CO}_{3}^{2-}$ [6].

\section{Classical Enzyme Kinetics and Ureolytic Catalysis}

\subsection{Historical Development of Enzyme Kinetics}

Table 1 presents a summary of the historical development of enzyme kinetics, which is the study of the factors that determine the speed of enzyme-catalysed reactions. A fundamental quantitative description of enzymatic reactions was first proposed almost a century ago by Michaelis and Menten [10]. In their model, a time-independent hyperbolic relationship was proposed between the initial reaction velocity and initial substrate concentration. The model was developed based on a quasi-steady-state approximation (QSSA) and assumed that during an enzymatic reaction the reactant concentration changes very slowly (as if in a quasi-steady state) after an initial short transient period. This approximation was first validated and discussed by Laidler [42], who found for a quasi-steady-state condition to exist the substrate concentration should be high. Since then, validation of the QSSA and development of methods to solve the rate equations have both been studied extensively. For example, the range of validity for the QSSA for both irreversible and reversible Michaelis-Menten reactions was assessed by Hommes [43], who observed that the QSSA may not be applicable for a reaction with large reverse bimolecular velocity. Wong [44] stated that for the QSSA to be applicable, the transient state must be brief, which can be achieved by increasing the substrate/enzyme ratio. Similarly, Stayton and Fromm [45] found that for the QSSA to hold, the substrate/enzyme concentration ratio should be greater than 100 .

The integrated Michaelis-Menten equation in its closed form was first reported by Beal [46] using either a table called the function ' $\mathrm{F}$ ' or a Newton's root-finding method. Based on the assumptions of the QSSA, Schnell and Mendoza [47] were the first to develop a closed-form solution for the time evolution of the basic enzyme-substrate reaction as proposed by Michaelis and Menten [10]. The results from their study indicated that a closed-form solution of the basic enzyme-substrate reaction could be expressed in terms of the Lambert $\mathrm{W}(\mathrm{x})$ function [48,49]. However, Tzafriri [50] noted that at higher intra-cellular enzyme concentrations, or at least at the same concentrations as their substrates, the QSSA condition breaks down under in vivo conditions. Tzafriri [50] re-developed a closed-form equation for the time-course substrate depletion of the Michaelis-Menten kinetics reaction at high enzyme concentrations. In recent years, various computer programs have been developed to solve the integrated Michaelis-Menten equation using ordinary differential (rate) equations and non-linear regression analysis [12,51-53]. 
Table 1. A summary of the historical developments in enzyme kinetics study.

\begin{tabular}{ccc}
\hline Year & Historical Achievement & Reference \\
\hline 1913 & Proposed the basic description of enzymatic reactions. & Michaelis and Menten [10] \\
1955 & Stated that for QSSA, there should be an excess in substrate concentration. & Laidler [42] \\
1962 & Observed that QSSA may not hold for a reaction with large reverse & Hommes [43] \\
1965 & bimolecular velocity. & Wong [44] \\
1979 & Stated that a brief transient state is required for QSSA. & Stayton and Fromm [45] \\
1997 & Found that for QSSA to hold, the substrate/enzyme ratio should be $>100$. & Schnell and Mendoza [47] \\
2003 & Developed a closed-form solution for the basic enzyme-substrate reaction. & Tzafriri [50] \\
Redeveloped a closed-form solution at high enzyme concentrations. & Johnson [12], Kuzmič [51], \\
& Development of various computer programs to solve the integrated & Zavrel, Kochanowski [53] \\
\hline
\end{tabular}

\subsection{Enzyme-Catalysed Reaction Methods}

Two common approaches are used for the measurement of enzyme properties and activity, namely, discontinuous and continuous approaches. In EICP, the discontinuous approach involves mixing the substrates (urea and $\mathrm{CaCl}_{2}$ ) and enzyme together and measuring the product $\left(\mathrm{CaCO}_{3}\right)$ formed after a set period. The chemical equations involved in this reaction are described in Equations (1)-(5) [40]. This approach has been widely used in a number of studies to quantify the $\mathrm{CaCO}_{3}$ precipitation ratio (PR) [5,17-19]. PR is the ratio of the mass of precipitated $\mathrm{CaCO}_{3}$ to the theoretically possible maximum precipitation mass, which depends on the concentrations of various chemicals in the solution $[5,17-21,54]$. However, the discontinuous approach cannot be used to capture the catalytic properties of the enzyme-catalysed reaction, such as the influence of urease activity and product inhibition. The continuous method of enzyme assay involves the study of the rate of an enzyme-catalysed reaction by mixing the enzyme with the substrate (mostly urea) and continuously measuring the product $\left(\mathrm{e} . \mathrm{g} \mathrm{NH}_{4}\right.$ ) formed or the dissociation of the substrate over time.

Figure 2 shows reactions rates for typical continuous enzyme assays. Figure 2a shows the product formation over time which starts at a faster rate but slows down over time. The reduction in the speed of the reaction could be caused by the following reasons: (1) the substrate within the mixture is being used up and thus becomes a limiting factor, (2) the enzyme is unstable and is denaturing over the course of the experiment, and/or (3) the reaction environment (such as $\mathrm{pH}$ and temperature) is changing. The rate of the reaction is usually specified for the initial stages when none of the above-mentioned conditions applies. For example, the velocity of the reaction at the initial stage is referred to as the initial velocity $\left(\mathrm{V}_{0}\right)$ [55]. Figure $2 \mathrm{~b}$ presents the relationship between enzyme concentration and the rate of the reaction, which shows a simple linear correlation. It is worth noting that for a sufficient substrate concentration, the reaction velocity increases with increasing enzyme concentration. A plot of initial reaction velocity versus substrate concentration, for the same enzyme concentration, is presented in Figure 2c, which shows that when the substrate concentration is increased, the rate of reaction increases considerably. However, as the substrate concentration is increased further the effects on the reaction rate start to diminish until a stage is reached where increasing the substrate concentration has a little further effect. At this point, the enzyme is considered to be approaching saturation with the substrate and develops its maximal velocity $\left(V_{\max }\right) . K_{m}$ is the substrate concentration at half the maximal velocity. 

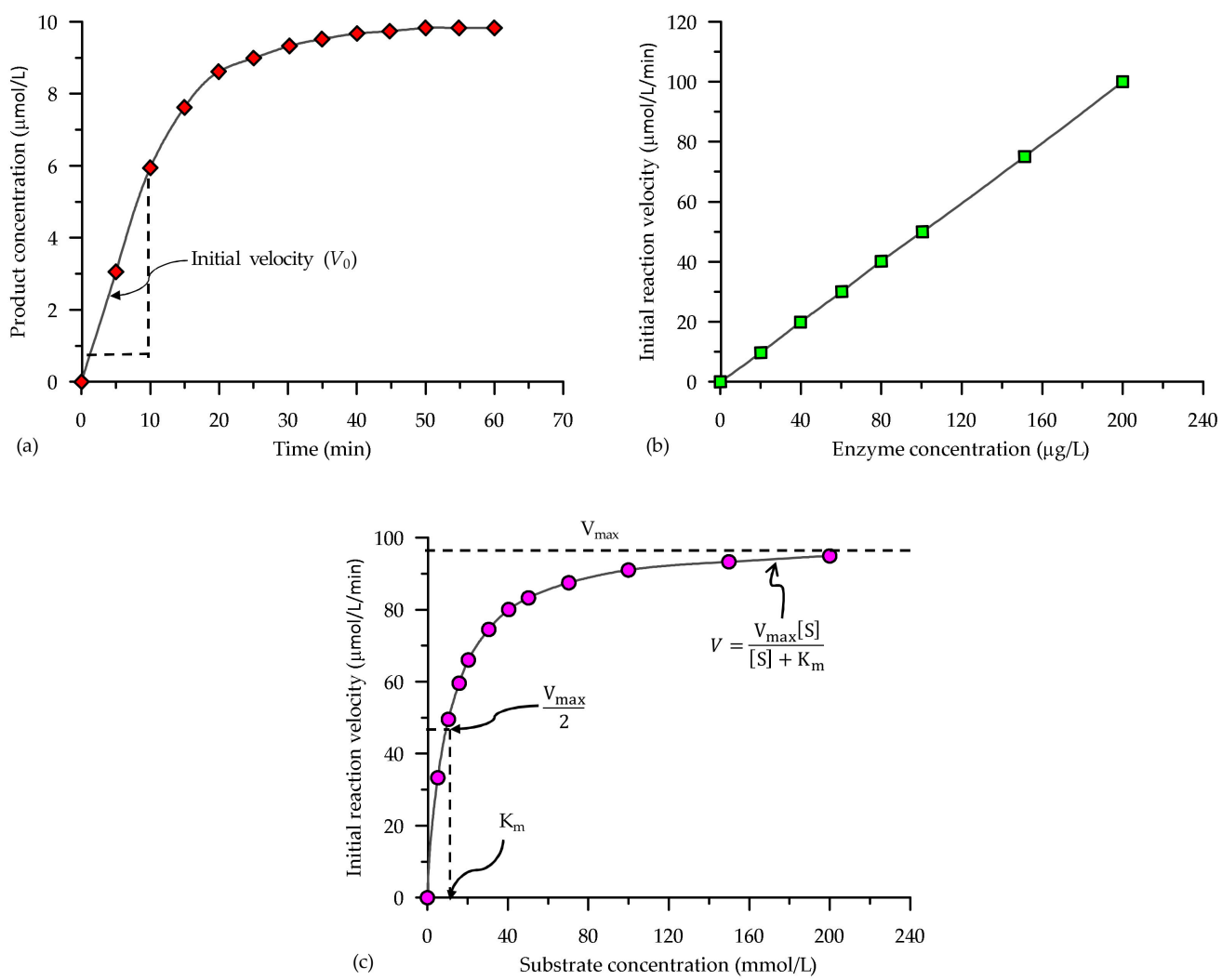

Figure 2. A typical enzyme-catalyzed reaction (a) product formation over time; (b) initial reaction velocity versus enzyme concentration; and (c) initial reaction velocity versus substrate concentration (data adapted from Robinson [55]).

\subsection{The Michaelis-Menten Equation}

The Michaelis-Menten Equation [10] states that in a typical enzymatic reaction, a substrate (S) interacts with an enzyme (E) forming an enzyme-substrate (ES) complex, which is subsequently activated into a transition state (ES). The latter (ES) is converted into an enzyme-product (EP) complex which eventually dissociates [10]. These steps are described in Equation (6):

$$
\mathrm{E}+\mathrm{S} \underset{\mathrm{k}_{-1}}{\stackrel{\mathrm{k}_{1}}{\leftrightarrows}} \mathrm{ES} \stackrel{\mathrm{k}_{\text {cat }}}{\rightarrow} \mathrm{E}+\mathrm{P}
$$

Here, $\mathrm{k}_{1}$ is the rate constant for the formation of the ES complex, $\mathrm{k}_{-1}$ is the rate constant for the dissociation of the ES complex, while $\mathrm{k}_{\mathrm{cat}}\left(\mathrm{S}^{-1}\right)$ is the catalytic rate constant or a turnover number and is defined as the rate of product formation when the enzyme is saturated with substrate, and therefore reflects the enzyme's maximum reaction rate.

To quantify the rate of product formation in an enzymatic reaction, the QSSA is used, which assumes that the rate of change in ES remains essentially constant. Under these conditions, the reaction's rate $(\mathrm{V})$ can be expressed as Equation (7):

$$
\text { reaction rate }=\mathrm{V}=\frac{\mathrm{d}[\mathrm{P}]}{\mathrm{dt}}=\mathrm{k}_{\mathrm{cat}}[\mathrm{ES}]
$$

where [] indicates the molar concentration of the material enclosed. For an enzyme's original concentration of $[\mathrm{E}]_{0},[\mathrm{ES}]$ can be expressed as Equation (8):

$$
[\mathrm{ES}]=\frac{[\mathrm{E}]_{0} \cdot[\mathrm{S}]}{\mathrm{K}_{\mathrm{m}}+[\mathrm{S}]}
$$


Now, by combining Equations (7) and (8):

$$
\mathrm{V}=\frac{\mathrm{d}[\mathrm{P}]}{\mathrm{dt}}=\frac{\mathrm{k}_{\mathrm{cat}} \cdot[\mathrm{E}]_{\mathrm{O}} \cdot[\mathrm{S}]}{\mathrm{K}_{\mathrm{m}}+[\mathrm{S}]}
$$

For high substrate concentrations, $[S] \gg K_{m}$, the reaction rate in Equation (9) can be expressed as:

$$
\mathrm{V}=\frac{\mathrm{d}[\mathrm{P}]}{\mathrm{dt}}=\frac{\mathrm{k}_{\mathrm{cat}} \cdot[\mathrm{E}]_{0} \cdot[\mathrm{S}]}{\mathrm{K}_{\mathrm{m}}+[\mathrm{S}]} \approx \frac{\mathrm{k}_{\mathrm{cat}} \cdot[\mathrm{E}]_{\mathrm{O}} \cdot[\mathrm{S}]}{[\mathrm{S}]}=\mathrm{k}_{\mathrm{cat}} \cdot[\mathrm{E}]_{0}=\mathrm{V}_{\max }
$$

For low substrate concentrations, $[S] \ll K_{m}$, Equation (9) can again be expressed as Equation (11):

$$
\mathrm{V}=\frac{\mathrm{d}[\mathrm{P}]}{\mathrm{dt}}=\frac{\mathrm{k}_{\mathrm{cat}} \cdot[\mathrm{E}]_{0} \cdot[\mathrm{S}]}{\mathrm{K}_{\mathrm{m}}+[\mathrm{S}]} \approx \frac{\mathrm{k}_{\mathrm{cat}} \cdot[\mathrm{E}]_{0} \cdot[\mathrm{S}]}{\mathrm{K}_{\mathrm{m}}}=\frac{\mathrm{V}_{\mathrm{max}} \cdot[\mathrm{S}]}{\mathrm{K}_{\mathrm{m}}}
$$

Equation (9) is known as the Michaelis-Menten equation [10] which shows the rectangular hyperbolic nature of $\mathrm{V}$, having an asymptote at $\mathrm{V}=\mathrm{V}_{\max }$. This provides a relationship between the reaction rate and the substrate concentration, depending on two kinetic parameters, the Michaelis constant, $\mathrm{K}_{\mathrm{m}}(\mathrm{M})$ and the catalytic rate constant $\mathrm{k}_{\text {cat }}\left(\mathrm{S}^{-1}\right)$. For any given enzyme/substrate pair, $\mathrm{K}_{\mathrm{m}}$ is constant and measures the efficiency of an enzyme to convert substrates into products. Small $\mathrm{K}_{\mathrm{m}}$ values (i.e., $\mathrm{K}_{\mathrm{m}}<1 \mathrm{mM}$ ) indicate that $\mathrm{V}_{\max }$ is reached at relatively low substrate concentrations and vice versa. The rate of product formation is dependent on both how well the enzyme binds the substrate and how fast the enzyme converts the substrate into the product once the substrate is bound. For a kinetically perfect enzyme, every encounter between enzyme and substrate leads to the formation of a product, hence the reaction velocity is only limited by the rate the enzyme encounters the substrate in solution. The $\mathrm{k}_{\text {cat }} / \mathrm{K}_{\mathrm{m}}$ ratio is called the "specificity constant" which measures how efficiently an enzyme converts the substrate into a product.

\section{Estimation of Kinetic Parameters}

According to Michaelis and Menten [10], a plot of the reaction rate versus initial substrate concentration produces a saturation curve from which $\mathrm{K}_{\mathrm{m}}$ and $\mathrm{V}_{\max }$ can be obtained using non-linear regression analysis. Alternative approaches have also been reported in the literature to provide a linear transformation of the Michaelis-Menten equation for prediction and determination of the kinetic parameters [56-59]. The most common methods in the literature are the Lineweaver and Burk [57] plot, the HanesWoolf [58] plot and the Eadie-Hofstee [60] plot. The Hanes-Woolf plot [58] involves a graphical method where the ratio of the initial substrate concentration [S] to the reaction velocity (V) is plotted against [S] (Figure 3). This is based on the rearrangement of the Michaelis-Menten equation (see Equation (9)), as presented below:

$$
\frac{[\mathrm{S}]}{\mathrm{V}}=\frac{[\mathrm{S}]}{\mathrm{V}_{\max }}+\frac{\mathrm{K}_{\mathrm{m}}}{\mathrm{V}_{\max }}
$$

It is evident from Equation (12) that a kinetic reaction will yield a straight line of slope $1 / \mathrm{V}_{\max }$, a $\mathrm{y}$-intercept of $\mathrm{K}_{\mathrm{m}} / \mathrm{V}_{\max }$ and an $\mathrm{x}$-intercept of $-\mathrm{K}_{\mathrm{m}}$ as graphically presented in Figure 3.

The linear transformation of the Michaelis-Menten equation by Lineweaver and Burk [57] is presented in Equation (13). Similar to the Hanes-Woolf plot [58], a kinetic reaction will yield a straight line of slope $K_{m} / V_{\max }$, a y-intercept of $1 / V_{\max }$ and an $x-$ intercept of $-1 / \mathrm{K}_{\mathrm{m}}$, as shown graphically in Figure 4.

$$
\frac{1}{\mathrm{~V}}=\frac{\mathrm{K}_{\mathrm{m}}}{\mathrm{V}_{\max }} \cdot \frac{1}{[\mathrm{~S}]}+\frac{1}{\mathrm{~V}_{\max }}
$$




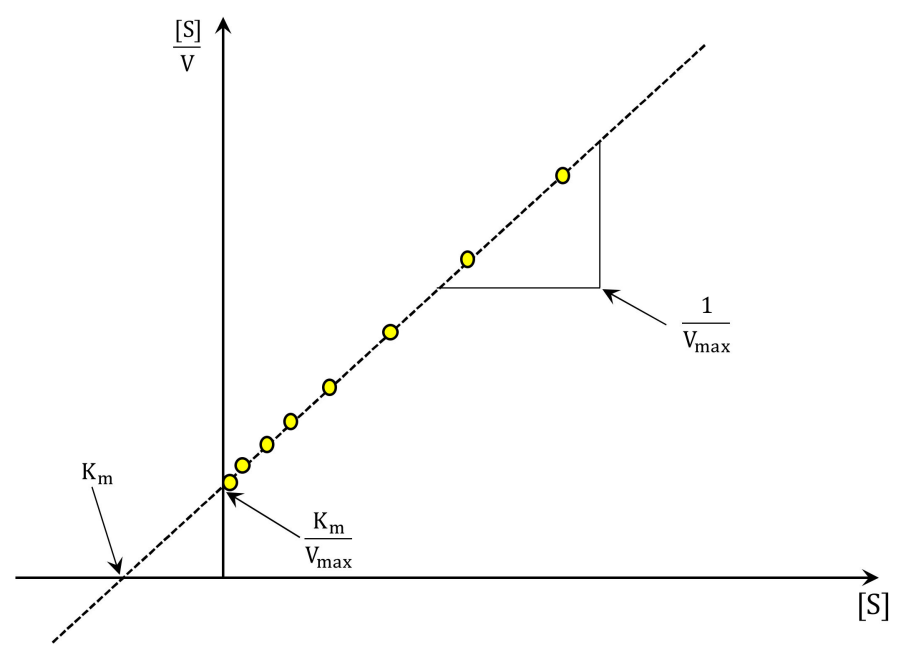

Figure 3. A graphical representation of the Hanes-Woolf plot.

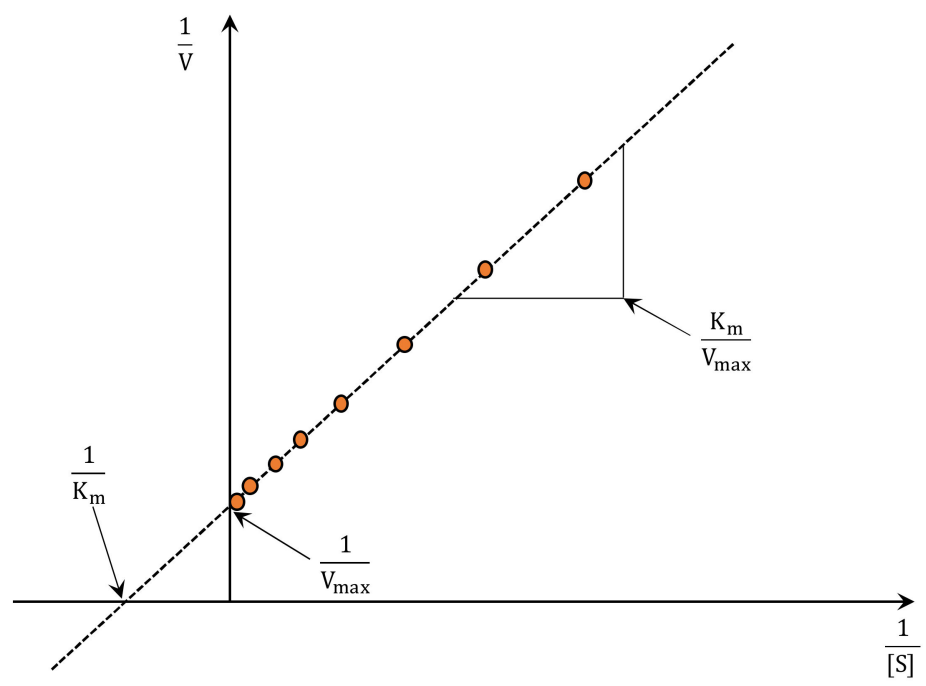

Figure 4. A graphical representation of the Lineweaver-Burk plot.

In the method by Eadie-Hofstee [60], a plot is generated from $\mathrm{V} /[\mathrm{S}]$ versus $\mathrm{V}$ data, where the intercept is $\mathrm{V}_{\max }$ and the slope is $-\mathrm{K}_{\mathrm{m}}$ (Figure 5). The linear equation used to determine the kinetic parameters is given by Equation (14). Table 2 shows a summary of the relative advantages and limitations of these methods.

$$
\mathrm{V}=\mathrm{V}_{\max }-\mathrm{K}_{\mathrm{m}} \cdot \frac{\mathrm{V}}{[\mathrm{S}]}
$$

Table 2. Comparison of different methods for the estimation of kinetic parameters.

\begin{tabular}{ccc}
\hline Method & Advantage & Limitation \\
\hline $\begin{array}{c}\text { Lineweaver } \\
\text { and Burk [57] }\end{array}$ & (1) Gives a good estimation of $\mathrm{V}_{\max }$ and $\mathrm{K}_{\mathrm{m}} \cdot$ & $\begin{array}{c}\text { (1) Poor fit between data and straight line. } \\
\text { (2) Large error at low }[S] \text { where measurements are less accurate. }\end{array}$ \\
\hline $\begin{array}{c}\text { Hanes-Woolf } \\
\text { plot [58] }\end{array}$ & (1) Direct determination of $\mathrm{V}_{\max }$ and $\mathrm{K}_{\mathrm{m} .}$ & $\begin{array}{c}\text { (1) Both axes contain an independent variable. } \\
\text { (2) large error at low }[S] .\end{array}$ \\
\hline $\begin{array}{c}\text { Eadie-Hofstee } \\
\text { plot [60] }\end{array}$ & (1) Less error observed at low $[\mathrm{S}]$. & (2) The dependent variable (V) occurs in both the X-and Y-axes. \\
\hline
\end{tabular}




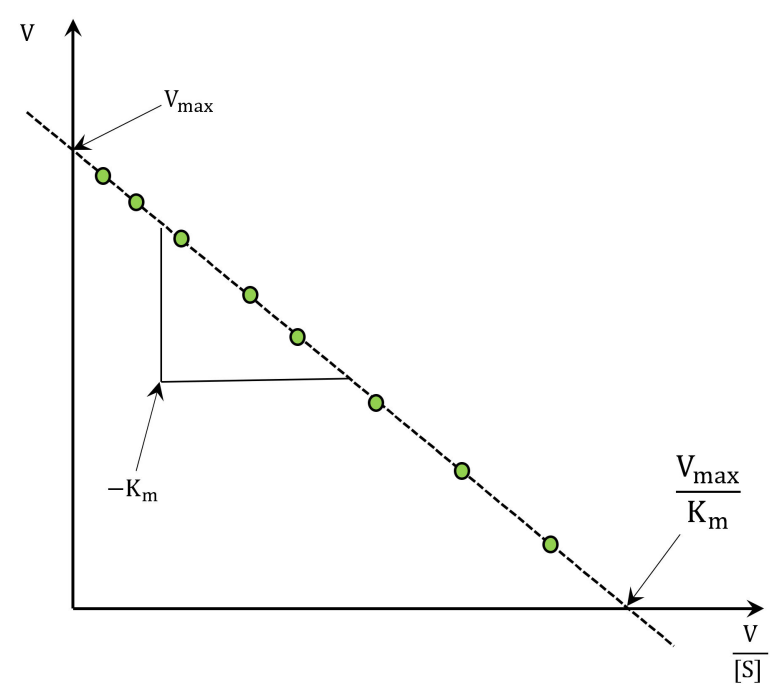

Figure 5. A graphical representation of the Eadie-Hofstee plot.

Despite the relative advantages and disadvantages of each method, the accuracy of estimating kinetic parameters is largely influenced by $\mathrm{pH}$, temperature and the presence of inhibitors. Hence, the methods discussed earlier may not fully capture the kinetic properties of an enzyme-catalyzed reaction, specifically during $\mathrm{CaCO}_{3}$ precipitation in EICP. Urease inhibitors are discussed in more detail in Section 6.

\subsection{Integrated Michaelis-Menten Rate Equations}

The integrated Michaelis-Menten rate equation provides an alternative way of expressing the rate of product formation in terms of the constituent conecentrations and the kinetic parameters [61-64]. Equation (9) can be expressed as:

$$
\mathrm{V}=\frac{\mathrm{d}[\mathrm{P}]}{\mathrm{dt}}=\frac{\mathrm{V}_{\max } \cdot[\mathrm{S}]}{\mathrm{K}_{\mathrm{m}}+[\mathrm{S}]}
$$

Equation (15) is a separable differential equation and can be integrated with respect to time between 0 and $t$ (where time zero represents the onset of steady-state), as below:

$$
\ln [S]_{\mathrm{t}}+[\mathrm{S}]_{\mathrm{t}}=\mathrm{K}_{\mathrm{m}} \cdot \ln [\mathrm{S}]_{\mathrm{o}}-[\mathrm{S}]_{0}-\mathrm{V}_{\max } \cdot \mathrm{t}
$$

where $\mathrm{V}=[\mathrm{P}]_{\mathrm{t}}=-[\mathrm{S}]_{\mathrm{t}}=[\mathrm{S}]_{0}-[\mathrm{S}]_{\mathrm{t}}$.

Equation (16) gives the classical integrated Michaelis-Menten equation which can be used to predict the reaction rate. A closed-form integrated rate equation greatly simplifies and facilitates the nonlinear evaluation of the kinetic parameters $\left(\mathrm{K}_{\mathrm{m}}\right.$ and $\left.\mathrm{V}_{\max }\right)$ and provides a direct prediction of the substrate or product concentration at different time values $(\mathrm{t})$ during the steady-state.

\subsection{Closed-Form Solution of the Rate Equation}

Johnson and Goody [65] provided a reanalysis of the original data of Michaelis and Menten [10] using the direct solution of Equation (16). In their study, modern computational methods based on numerical integration of rate equations were used to fit the original data of Michaelis and Menten [10]. The KinTek Explorer simulation program [12] was used in their study. The authors produced a fitting plot of the $[\mathrm{P}]_{t} /[\mathrm{S}]_{0}$ ratio against reaction time. The results from their study showed that a good fit can be achieved by considering the influence of product inhibition in the rate equation. The findings presented by Johnson and Goody [65] suggest that the specificity constant $\left(\mathrm{k}_{\mathrm{m}}=\mathrm{k}_{\mathrm{cat}} / \mathrm{K}_{\mathrm{m}}\right)$ is the most important steady 
state kinetic parameter in that it defines enzyme specificity, efficiency and proficiency. They proposed a different form of the Michaelis-Menten equation, as shown in Equation (17):

$$
\mathrm{V}=\frac{\mathrm{k}_{\mathrm{m}} \cdot[\mathrm{S}]}{1+\left(\mathrm{k}_{\mathrm{m}} / \mathrm{k}_{\mathrm{cat}}\right) \cdot[\mathrm{S}]}
$$

Therefore, the closed-form solution of Equation (16) can be expressed in terms of the Lambert W(x) function [47], as presented in Equation (18):

$$
[S]_{\mathrm{t}}=\mathrm{K}_{\mathrm{m}} \cdot \mathrm{W}\left\{\frac{[\mathrm{S}]_{0}}{\mathrm{~K}_{\mathrm{m}}} \cdot \exp \left(\frac{[\mathrm{S}]_{0}-\mathrm{V}_{\max } \cdot \mathrm{t}}{\mathrm{K}_{\mathrm{m}}}\right)\right\}
$$

It should be noted that Equation (18) is accurate when the criterion for total enzyme concentration $[\mathrm{E}]_{0}<<\left([S]_{0}+K_{m}\right)$ guarantees the validity of the QSSA [47]. In the case of most in vitro assays, the QSSA criterion is satisfied easily. However, for in vivo conditions where intracellular concentrations of the enzyme are usually higher or at least of the same magnitude as their substrates, the QSSA condition does not hold [50]. Therefore, Tzafriri [50] proposed an extended equation for high enzyme concentrations, as shown in Equation (19):

$$
[S]_{\mathrm{t}}=\left(\mathrm{K}_{\mathrm{m}}+[\mathrm{E}]_{0}\right) \cdot \mathrm{W}\left\{\frac{[\mathrm{S}]_{0}}{\mathrm{~K}_{\mathrm{m}}+[\mathrm{E}]_{0}} \cdot \exp \left(\frac{[\mathrm{S}]_{0}-\mathrm{V}_{\mathrm{max}} \cdot \mathrm{t}}{\mathrm{K}_{\mathrm{m}}+[\mathrm{E}]_{0}}\right)\right\}
$$

Note that Equation (19) is valid when $\left.[E]_{0}+K_{\mathrm{m}}>>S\right]_{0}$.

In a recent study conducted by Goličnik [66], a global nonlinear regression was used to model the kinetic parameters using the original data obtained by Michaelis and Menten [10]. Goličnik [66] reformulated Equation (16) to achieve the $[P]_{\mathrm{t}} /[S]_{0}$ ratio as originally used by Johnson and Goody [65], as presented in Equation (20):

$$
[\mathrm{P}]_{\mathrm{t}} /[\mathrm{S}]_{0}=1-\frac{\mathrm{K}_{\mathrm{m}}}{[\mathrm{S}]_{0}} \cdot \mathrm{W}\left\{\frac{[\mathrm{S}]_{0}}{\mathrm{~K}_{\mathrm{m}}} \cdot \exp \left(\frac{[\mathrm{S}]_{0}-\mathrm{V}_{\max } \cdot \mathrm{t}}{\mathrm{K}_{\mathrm{m}}}\right)\right\}
$$

Goličnik [66] used a numerical integration approach to fit the original MichaelisMenten results using the exact model of Equation (20) with the Lambert W(x) function obtained using a computer program (Mathematica 7).

\section{Applications of Enzyme Kinetic Models in EICP}

In relation to the Michaelis-Menten Equation [10], a similar enzymatic reaction occurs during urea hydrolysis in EICP where urea interacts with the enzyme at a constant rate. The concentration and activity of urease enzyme can be used to develop a relation to determine the catalytic rate during urea hydrolysis for a given urea concentration. However, the reaction products (i.e., $\mathrm{NH}_{4(\mathrm{aq})}^{+}$and $\mathrm{CO}_{3}^{2-}(\mathrm{aq})$ ) can exist in different forms in an aqueous solution, which may affect the reaction rate. In EICP, the addition of calcium salt, changes in the geochemical environment ( $\mathrm{pH}$, temperature, heavy metals etc.) of soils/concrete may significantly affect the catalytic rate/kinetic parameters [67]. However, the influence of urease enzyme concentration and activity, geochemical environment and so forth on the catalytic rate and efficiency of $\mathrm{CaCO}_{3}$ precipitation during the EICP process has not been investigated. Therefore, a simple but reliable kinetic expression for evaluating the catalytic reaction in EICP is required. This study, through a comprehensive meta-analysis of data from literature, attempts to correlate the initial ratios, concentration and the catalytic effect of chemical constituent (urease enzyme, urea and $\left.\mathrm{CaCl}_{2}\right)$ with product $\left(\mathrm{CaCO}_{3}\right)$ formation rate. 


\subsection{Factors Affecting the Kinetic Parameters}

5.1.1. $\mathrm{pH}$

A range of standard kinetic parameters (i.e., $\mathrm{K}_{\mathrm{m}}$ and $\mathrm{V}_{\mathrm{max}}$ ) for urea hydrolysis catalysed by Jack bean urease enzyme have been reported in the literature $[68,69]$. However, $\mathrm{K}_{\mathrm{m}}$ and $\mathrm{V}_{\text {max }}$ are largely influenced by $\mathrm{pH}$ which consequently affects the kinetic reaction through perturbation of the distribution of enzyme [70-72]. Barth and Michel [73] investigated the activity of urease enzyme in the $\mathrm{pH}$ range of 4-9 and indicated that both $\mathrm{K}_{\mathrm{m}}$ and $\mathrm{V}_{\max }$ depend on $\mathrm{pH}$. The results from their study show a minimum value of $\mathrm{K}_{\mathrm{m}}$ at $\mathrm{pH} 7$, whereas $\mathrm{V}_{\max }$ was maximum at the same $\mathrm{pH}$. Similarly, Fidaleo and Lavecchia [71] evaluated the dependency of $\mathrm{K}_{\mathrm{m}}$ and $\mathrm{V}_{\max }$ on $\mathrm{pH}$ by assuming the enzymatic urea hydrolysis described by Tipton and Dixon [70] based on Equation (6), which is schematically illustrated in Figure 6.

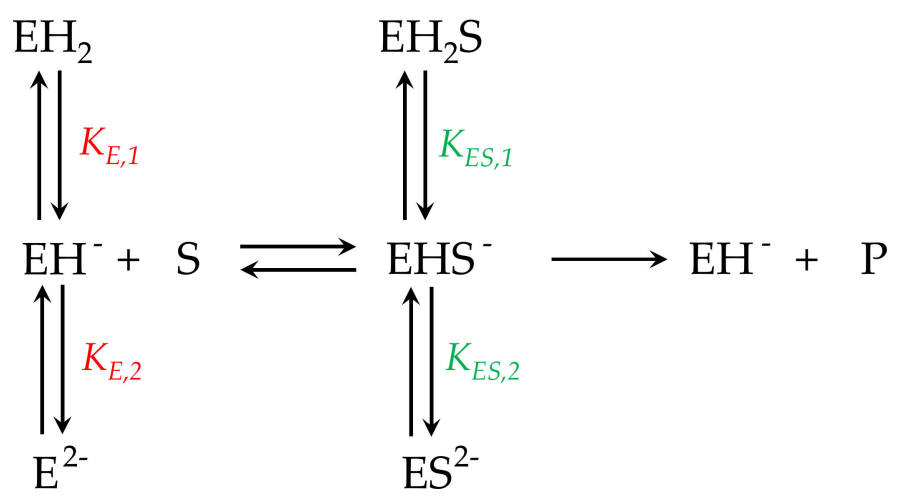

Figure 6. A schematic diagram of used to describe $\mathrm{pH}$ effects on the enzymatic urea hydrolysis.

$\mathrm{K}_{\mathrm{E}, 1}$ and $\mathrm{K}_{\mathrm{E}, 2}$ represent the molecular dissociation constants for the free enzyme whereas $\mathrm{K}_{\mathrm{ES}, 1}$ and $\mathrm{K}_{\mathrm{ES}, 2}$ represent the molecular dissociation constants for the enzymesubstrate complex. Hence, Fidaleo and Lavecchia [71] proposed an expression for $\mathrm{K}_{\mathrm{m}}$ and $\mathrm{V}_{\max }$ as presented in Equations (21) and (22), respectively.

$$
\begin{gathered}
\mathrm{K}_{\mathrm{m}}(\mathrm{pH})=\mathrm{K}_{\mathrm{m} 0} \frac{1+\frac{\left[10^{-\mathrm{pH}}\right]}{\mathrm{K}_{\mathrm{E}, 1}}+\frac{\mathrm{K}_{\mathrm{E}, 2}}{\left[10^{-\mathrm{pH}}\right]}}{1+\frac{\left[10^{-\mathrm{pH}}\right]}{\mathrm{K}_{\mathrm{ES}, 1}}+\frac{\mathrm{K}_{\mathrm{ES}, 2}}{\left[10^{-\mathrm{pH}}\right]}} \\
\mathrm{V}_{\max }(\mathrm{pH})=\frac{\mathrm{k}_{\mathrm{cat}} \cdot[\mathrm{E}]_{0}}{1+\frac{\left[10^{-\mathrm{pH}}\right]}{\mathrm{K}_{\mathrm{ES}, 1}}+\frac{\mathrm{K}_{\mathrm{ES}, 2}}{\left[10^{-\mathrm{pH}}\right]}}
\end{gathered}
$$

where $\mathrm{K}_{\mathrm{m} 0}$ is the initial $\mathrm{K}_{\mathrm{m}}$.

In Figure 7, the influence of $\mathrm{pH}$ (from 4-9) on $\mathrm{K}_{\mathrm{m}}$ and $\mathrm{V}_{\max }$ is presented using data obtained from the literature [71]. It is interesting to note from Figure 7 that $\mathrm{pH}$ has a much higher effect on $\mathrm{V}_{\max }$ compared to the effect on $\mathrm{K}_{\mathrm{m}}$.

\subsubsection{Temperature}

In a kinetic reaction, $\mathrm{k}_{\mathrm{cat}}$ is the only temperature-dependent parameter and has often been adjusted to capture the influence of temperature variations. Fidaleo and Lavecchia [71] studied the influence of temperature $\left(25\right.$ and $\left.37^{\circ} \mathrm{C}\right)$ on the reaction rate. They proposed an expression for $\mathrm{k}_{\mathrm{cat}}$ in terms of the activation energy of urea hydrolysis as presented in Equation (23) below.

$$
\mathrm{k}_{\mathrm{cat}}(\mathrm{T})=\exp \left[-\frac{\mathrm{E}_{\mathrm{a}}}{\mathrm{R}}\left(\frac{1}{\mathrm{~T}}-\frac{1}{\mathrm{~T}^{*}}\right)\right]
$$


where $E_{a}$ is the activation energy, $R$ is the gas constant and $T^{*}$ is the temperature at which $\mathrm{k}_{\mathrm{cat}}=1 \mathrm{~min}^{-1}$.

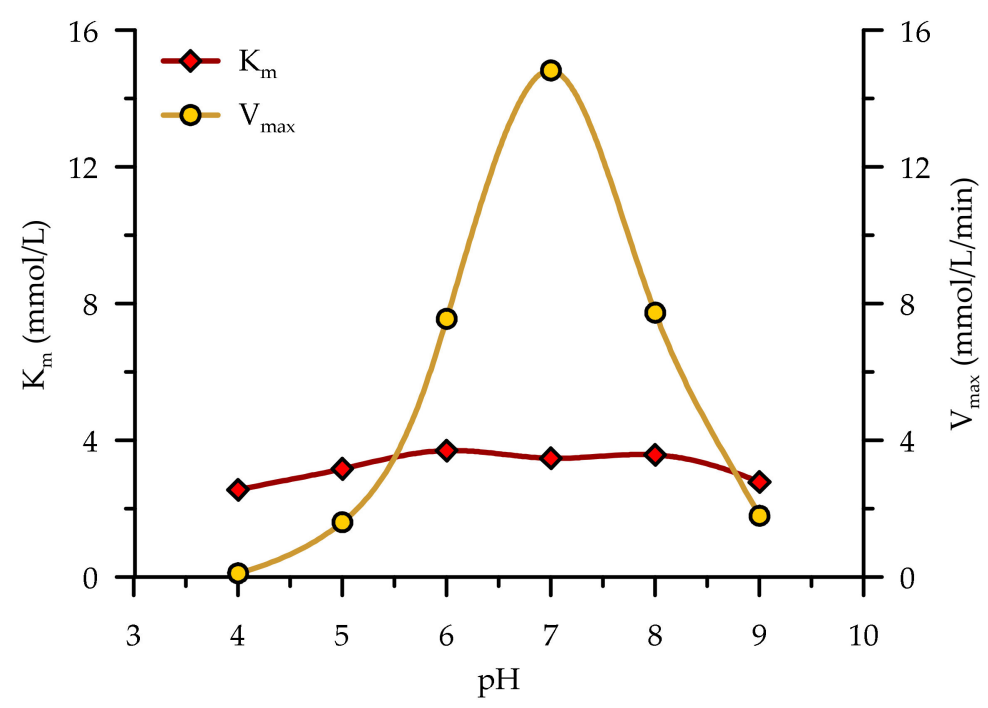

Figure 7. Effect of $\mathrm{pH}$ on $\mathrm{K}_{\mathrm{m}}$ and $\mathrm{V}_{\max }$ (data adapted from Fidaleo and Lavecchia [71]).

A parametric approach was recently used by Krajewska, van Eldik [72] to elucidate the influence of temperature $(\mathrm{T})$ on the steady-state kinetic parameter, i.e., $\mathrm{K}_{\mathrm{m}}$ and $\mathrm{k}_{\text {cat }}$. Note, $\mathrm{k}_{\text {cat }}$ is a direct measure of $\mathrm{V}_{\max }$. Their study indicated that $\mathrm{K}_{\mathrm{m}}$ controls the formation of the ES complex: $\mathrm{E}+\mathrm{S} \leftrightarrow \mathrm{ES}$, during the binding of the substrate, whereas $\mathrm{k}_{\text {cat }}$ controls the activation process of the ES complex: $\mathrm{ES} \rightarrow(\mathrm{ES}-\mathrm{EP})$, when bond reorganization leading to the formation of the products occurs. A plot of $\mathrm{K}_{\mathrm{m}}$ and $\mathrm{k}_{\mathrm{cat}}$ for a range of temperature is presented in Figure 8 using data obtained from previous study. It can be seen from Figure 8 that $K_{m}$ and $k_{c a t}$ increases with increasing temperature which may directly affect the kinetic rate reaction during urea hydrolysis.

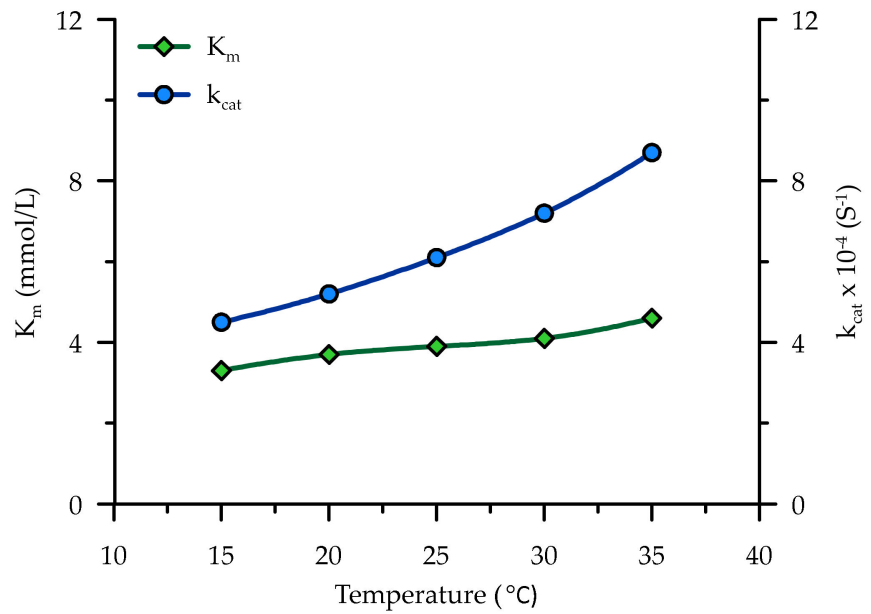

Figure 8. Effect of temperature on $\mathrm{K}_{\mathrm{m}}$ and $\mathrm{k}_{\mathrm{cat}}$ (data adapted from Krajewska, van Eldik [72]).

\subsubsection{Product Inhibition}

The rate of urea hydrolysis is mostly affected by the presence of in-vitro inhibitors, soil inhibitors and plant-soil inhibitors. From an enzyme kinetic point of view, these inhibitors can be classified into two groups i.e., competitive inhibitors where $\mathrm{V}_{\text {max }}$ remains the same but $\mathrm{K}_{\mathrm{m}}$ changes with the concentration of inhibitor and non-competitive inhibitor where $\mathrm{V}_{\max }$ changes with the concentration of inhibitor but $\mathrm{K}_{\mathrm{m}}$ is not affected as shown in Figure 9. 


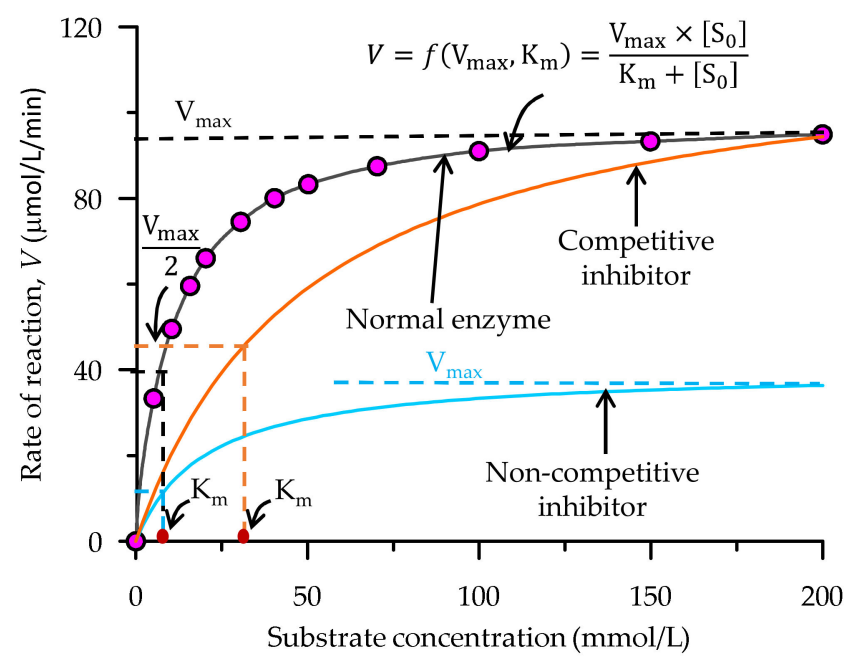

Figure 9. A graphical representation of the influence of inhibitors in an enzyme catalysed reaction.

The presence of ammonium ion in EICP acts as a non-competitive inhibitor and has been assessed in a number of studies $[10,12,65,66]$. Equation (24) below has been used in several studies to capture the effect of inhibitors on the reaction rate.

$$
\mathrm{V}=\frac{\mathrm{d}[\mathrm{P}]}{\mathrm{dt}}=\frac{\mathrm{V}_{\max } \cdot[\mathrm{S}]}{\left(1+\left[\mathrm{P}_{\mathrm{I}}\right] / \mathrm{K}_{\mathrm{P}}\right)\left(\mathrm{K}_{\mathrm{m}}+[\mathrm{S}]\right)}
$$

where $K_{P}$ and $\left[P_{I}\right]$ represent the apparent product inhibition constant and ammonium ion concentration, respectively.

A plot of $1 / \mathrm{V}$ versus $\left[\mathrm{P}_{\mathrm{I}}\right]$ i.e., ammonium ion concentration as a non-competitive inhibitor is presented in Figure 10 for $[\mathrm{S}]$ of 5 and $30 \mathrm{mmol} / \mathrm{L}$ using data from a previous study [71]. The tests were performed at a $\mathrm{pH}$ of 7 (using phosphate buffer), temperature of $25^{\circ} \mathrm{C}$, and a constant $[\mathrm{E}]_{0}$ of $0.1 \mathrm{~g} / \mathrm{L}$. By using Equation (24), a linear trend was observed for the experimental data using $\mathrm{k}_{\mathrm{cat}}=18.3 \mathrm{~min}^{-1}, \mathrm{~K}_{\mathrm{m}}=3.21 \mathrm{mmol} / \mathrm{L}$ and $\mathrm{K}_{\mathrm{P}}=12.2 \mathrm{mmol} / \mathrm{L}$. This shows that the presence of ammonium ions acts as a non-competitive inhibitor and influence the rate of urea hydrolysis.

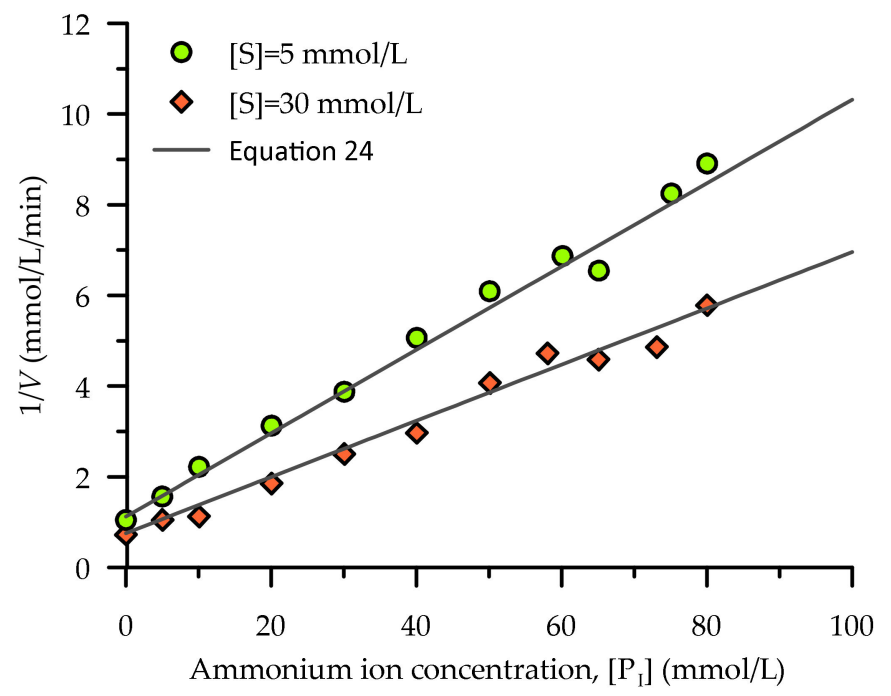

Figure 10. A linearised plot of $1 / \mathrm{V}$ versus $\left[\mathrm{P}_{\mathrm{I}}\right]$ for two different urea concentrations, fitted with Equation (24) (data adapted from Fidaleo and Lavecchia [71]). 


\subsection{Proposed Kinetic Model for EICP}

Laboratory testings on optimising the EICP process are often done at a constant temperature $\left(25-30^{\circ} \mathrm{C}\right)$ and $\mathrm{pH}$ of $7-8$ is maintained using buffer solution e.g., $130 \mathrm{mM}$ phosphate buffer. However, the geochemical environment in the field may differ from the controlled laboratory condition and will affect the reaction rate [38] and precipitation of $\mathrm{CaCO}_{3}$. For a potential application of the EICP technique, a comprehensive framework is required to capture the effect of different inhibitors under different temperatures as well as the $\mathrm{pH}$ of the reaction environment. A kinetic equation is proposed in this study by rearranging Equations (21)-(24). By assuming that $\mathrm{K}_{\mathrm{m}}$ is independent of $\mathrm{pH}$ (i.e., $\left.\mathrm{K}_{\mathrm{m}}(\mathrm{pH})=\mathrm{K}_{\mathrm{m} 0}\right)$ as indicated in previous studies [69,74]. Equation (25) can be expressed as:

$$
\mathrm{V}=\frac{\mathrm{d}[\mathrm{P}]}{\mathrm{dt}}=\frac{\mathrm{k}_{\mathrm{cat}}(\mathrm{T}) \cdot[\mathrm{E}]_{0} \cdot[\mathrm{S}]}{\left(\mathrm{K}_{\mathrm{m}}+[\mathrm{S}]\right)\left(1+\frac{\left[\mathrm{P}_{\mathrm{I}}\right]}{\mathrm{K}_{\mathrm{P}}}\right)\left(1+\frac{\left[10^{-\mathrm{pH}}\right]}{\mathrm{K}_{\mathrm{ES}, 1}}+\frac{\mathrm{K}_{\mathrm{ES}, 2}}{\left[10^{-\mathrm{pH}]}\right]}\right)}
$$

Based on results from previous studies, the kinetic parameters/constants for urea hydrolysis catalysed by Jack bean urease enzyme are summarised in Table 3.

Table 3. Estimated kinetic quantities for urea hydrolysis.

\begin{tabular}{cccc}
\hline Kinetic Parameters & Value & Unit & Reference \\
\hline $\mathrm{k}_{\mathrm{cat}}$ & $18.3 \pm 0.05$ & $\mathrm{~min}^{-1}$ & Fidaleo and Lavecchia [71] \\
$\mathrm{K}_{\mathrm{m}}$ & $3.21 \pm 0.36$ & $\mathrm{mmol} / \mathrm{L}$ & Fidaleo and Lavecchia [71] \\
$\mathrm{K}_{\mathrm{P}}$ & $12.2 \pm 0.11$ & $\mathrm{mmol} / \mathrm{L}$ & Fidaleo and Lavecchia [71] \\
$\mathrm{K}_{\mathrm{ES}, 1}$ & $7.57 \pm 0.41 \times 10^{-4}$ & $\mathrm{mmol} / \mathrm{L}$ & Fidaleo and Lavecchia [71] \\
$\mathrm{K}_{\mathrm{ES}, 2}$ & $1.27 \pm 0.08 \times 10^{-5}$ & $\mathrm{mmol} / \mathrm{L}$ & Fidaleo and Lavecchia [71] \\
$\mathrm{E}_{\mathrm{a}}$ & $32.6-35.8$ & $\mathrm{~kJ} / \mathrm{mol}$ & Martins, Cruz [75], Huang and Chen [76], Fidaleo and Lavecchia [71] \\
$\mathrm{T}^{*}$ & $416.6 \pm 0.50$ & $\mathrm{~K}$ & Fidaleo and Lavecchia [71] \\
\hline
\end{tabular}

\subsection{Evaluation of the Proposed Kinetic Equation}

Here, the proposed kinetic equation as presented in Equation (25) was evaluated using a series of kinetic studies in literature for urea hydrolysis catalysed by Jack bean urease enzyme. In Figure 11, the predictive capability of Equation (25) was assessed for a range of temperature using unbuffered and buffered experimental data. Figure 11a shows a plot of the reaction velocity versus urea concentration for the temperature of 25 and $37^{\circ} \mathrm{C}$. The trend of the data was fitted with Equation (25) using kinetic parameters indicated in Table 3. Despite the scatter of the unbuffered experimental data, the fitted equation/model accurately reproduces the experimental trends. A similar plot is presented in Figure 11b for a range of temperature between $15-35^{\circ} \mathrm{C}$ for buffered experimental data. Again, the kinetic equation captured the experimental data with reasonably high accuracy.

The proposed kinetic equation (Equation (25)) was further evaluated using data obtained in a previous study on EICP. The reaction rate, i.e., the rate of product formation, was modelled by using a closed-form solution of Equation (25) through a series of integral iterations in Microsoft Excel. This could also be achieved through other numerical approaches and programs as discussed in the previous sections. Note, the rate of $\mathrm{CaCO}_{3}$ formation in EICP is proportional to the formation or decomposition of other compounds such as $\mathrm{Ca}^{2+}, \mathrm{CO}_{3}^{2-}$ or $\mathrm{NH}_{4}^{+}$. Therefore, the rate of $\mathrm{Ca}^{2+}$ formation in EICP was evaluated using data from a previous study [67]. Only a few studies were available on EICP, and in most studies, the data required for the kinetic reaction modelling was not reported.

Figure 12 shows a plot of the product $\left(\mathrm{Ca}^{2+}\right)$ formation over time. The data were fitted with a closed-form solution of Equation (25) using the kinetic parameters presented in Table 3. The results show a good fit with some degree of deviations, possibly due to the influence of other environmental factors such as inhibitors or $\mathrm{pH}$ which were not reported for the data used. It is understood from this analysis that the kinetic equation can be used 
to model the reaction mechanism in EICP, however, further studies on the exact solution for Equation (25) is required for an accurate prediction.
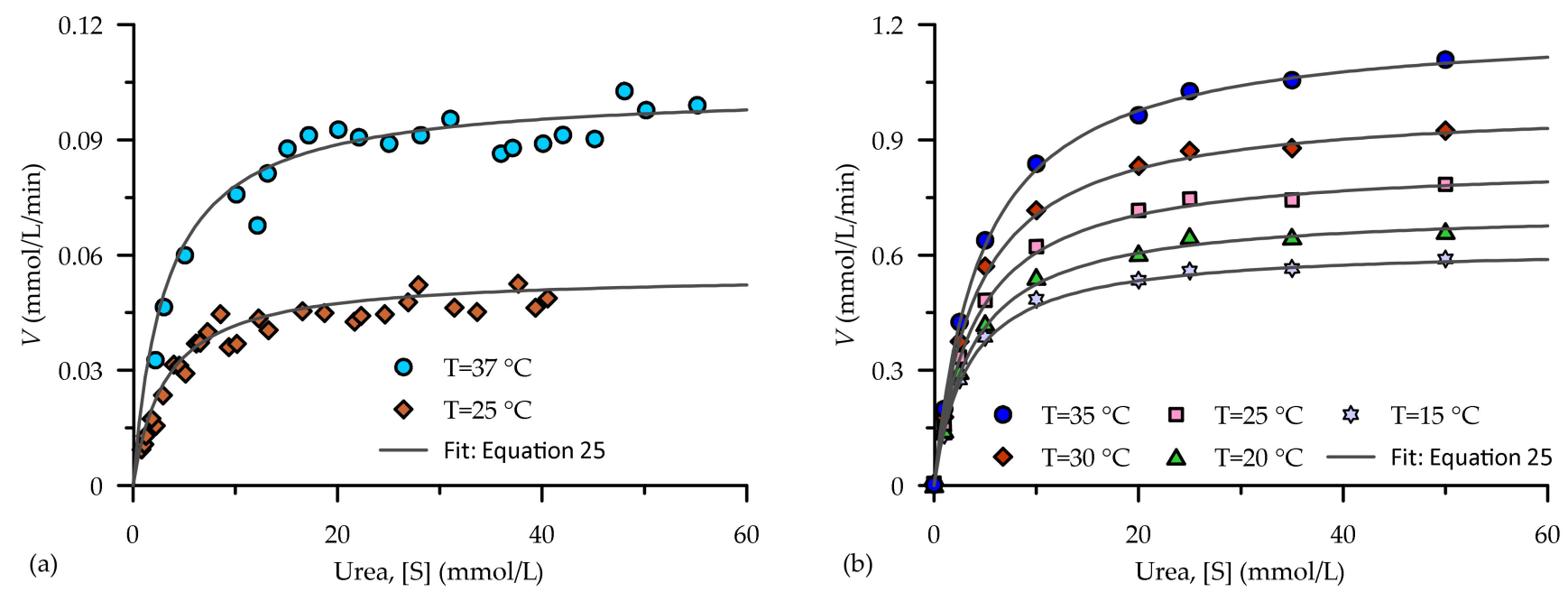

Figure 11. Reaction velocity versus urea concentration (a) unbuffered experimental data for $\mathrm{pH} 9.4$ and $\left[\mathrm{P}_{\mathrm{I}}\right]=0$. (data adapted from Fidaleo and Lavecchia [71]; and $(\mathbf{b})$ buffered experimental data for $\mathrm{pH} 6.84$ and $\left[\mathrm{P}_{\mathrm{I}}\right]=0$. (data adapted from Krajewska, van Eldik [72]).

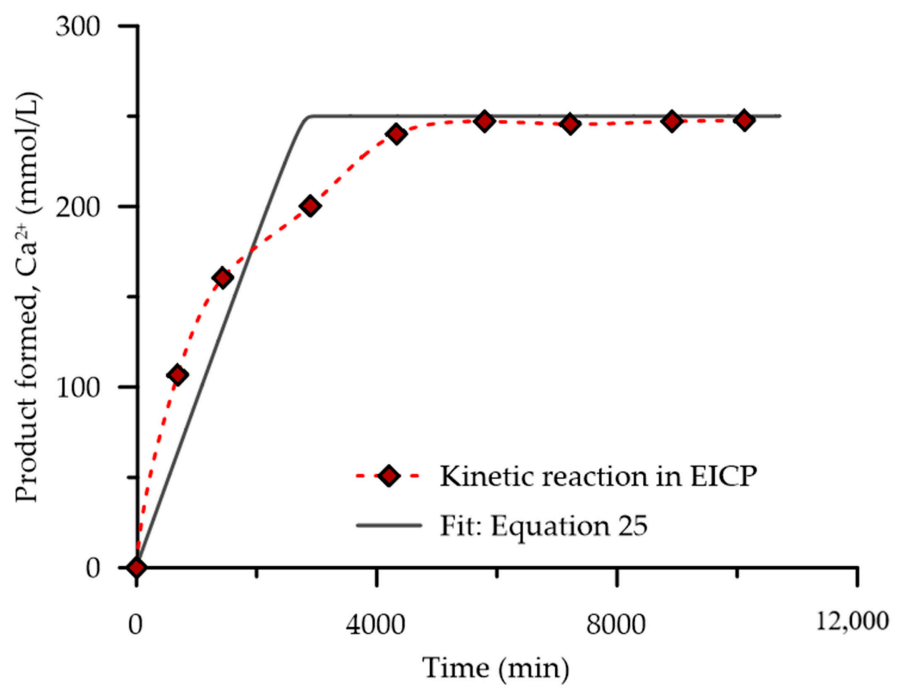

Figure 12. A plot of $\mathrm{Ca}^{2+}$ formation in EICP over time for $[\mathrm{E}]_{0}=8 \mathrm{~g} / \mathrm{L}$ (data adapted from Wen, $\mathrm{Li}$ [67]).

\section{Urease Inhibition}

Urease enzymes can be inhibited by a number of compounds. Inhibition studies are undertaken to provide insights into the molecular mechanisms of the urease action as well as to identify compounds that could effectively control enzyme activity. The substrate urea, urea analogues and ammonium ions (products of urea hydrolysis) are considered as weak inhibitors of urease. There are three common types of inhibition, which are competitive, non-competitive/mixed and uncompetitive inhibition.

Competitive inhibitors bind to the active site of the urease enzyme and prevent the substrate from binding. At low substrate concentrations, the presence of competitive inhibitors in an enzyme-catalysed reaction can significantly decrease the rate of the reaction. In EICP, the presence of competitive inhibitors such as heavy metal ions may affect the effectiveness of $\mathrm{CaCO}_{3}$ precipitation. However, this effect can be significantly reduced by increasing the substrate (urea-CaCl${ }_{2}$ ) concentration. Some studies have indicated that the presence of magnesium $[77,78]$ or anionic compounds such as polyelectrolytes [79-81] 
delays the rate of $\mathrm{CaCO}_{3}$ precipitation in EICP, which consequently alters the structure, size (approximately $10 \mu \mathrm{m}$ ) and quantity of the precipitated crystals. This may result in the precipitation of dolomite/magnesium carbonate $\left(\mathrm{MgCO}_{3}\right)$ or other polymorphs of $\mathrm{CaCO}_{3}$, which may affect the strength properties of EICP treated soil [54,77,78,82].

Non-competitive inhibitors allosterically bind the enzyme at a site other than the active site, thereby reducing the ability of the enzyme to perform its function. Hence, the velocity rate of the reaction usually asymptotes at lower than the maximum velocity. On the other hand, uncompetitive inhibitors bind the enzyme-substrate complex thereby resulting in an inactive enzyme-substrate complex. Uncompetitive and non-competitive inhibitors usually occur in a multiple-substrate system, such as in the case of EICP, and therefore this requires further investigation. A summary of the different sources of urease inhibitors in the literature is presented in Table 4.

Table 4. A summary of the historical developments in enzyme kinetics.

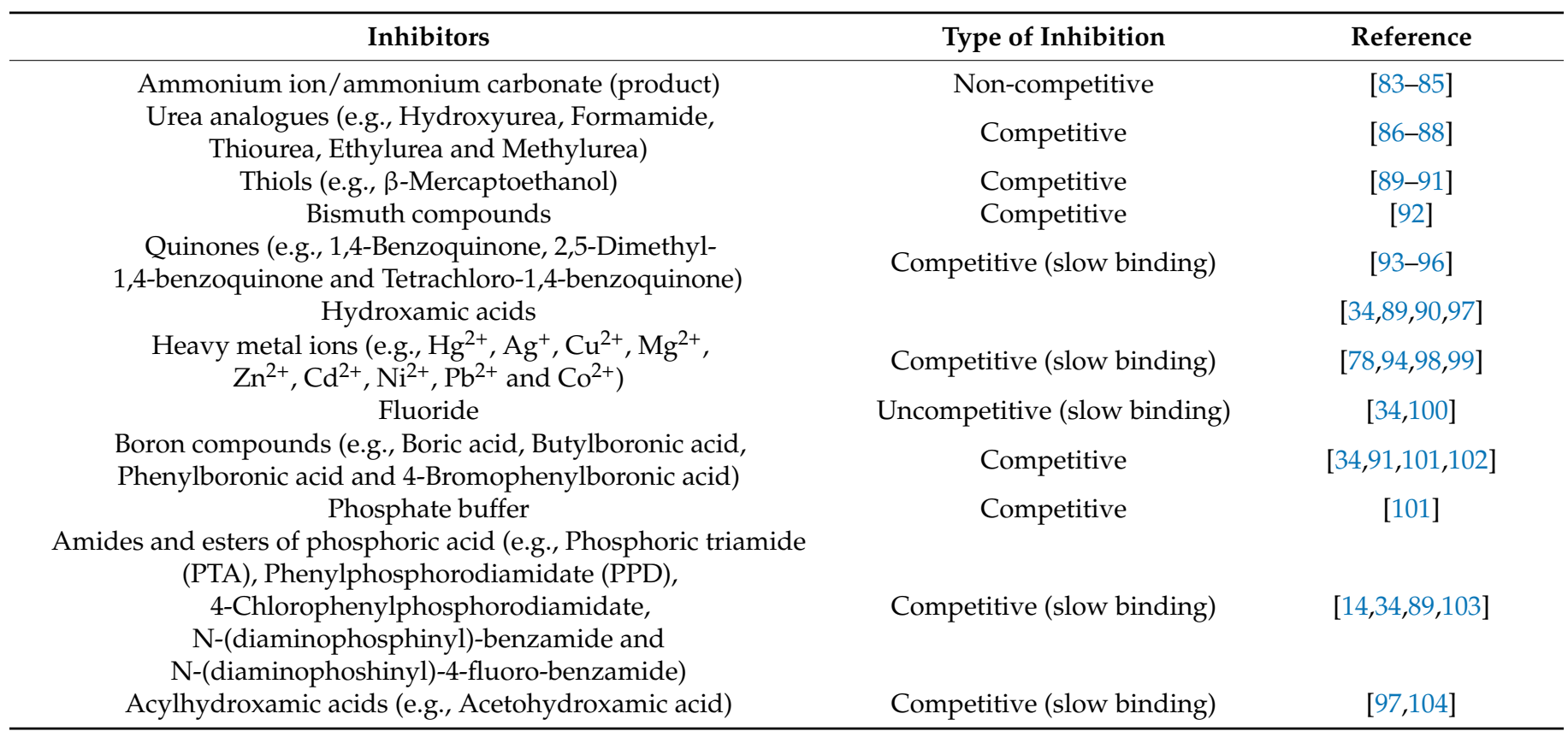

One way of controlling the action of urease is by immobilizing the enzyme [46]. Immobilization occurs when urease enzymes are physically confined or localised in a defined region of space with retention of their catalytic activities, which can be used repeatedly and continuously [15]. Even though upon immobilization the kinetic properties of enzymes may be degraded, their stabilities, operational lifetimes and sensitivities to inhibition $[11,16,90,105]$ are improved, thus providing robust and reliable enzyme preparations. Knowledge of urease inhibition and immobilization is significant for enhancing and controlling the rate of $\mathrm{CaCO}_{3}$ precipitation, as well as for the removal of contaminated ions or chemicals.

\section{Engineering Applications of Urease Aided- $\mathrm{CaCO}_{3}$ Precipitation}

7.1. Improvement of the Strength and Stiffness of Soils

In biocemented soils, the precipitated $\mathrm{CaCO}_{3}$ within the soil matrix provides bridges/ bonds between the grains of the soil particles, thereby restricting their movement and hence improving the strength and stiffness of the soil [18,106-108]. Application of EICP in soil strengthening and stabilisation can include crack remediation in concrete [109], strengthening of granular soil $[19,106,110,111]$ and liquefaction mitigation $[112,113]$.

Despite past works on the application of EICP for soil improvement, the overall controllability of the technique requires significant research. In EICP, it is often difficult to 
accurately predict and/or control the rate and amount of $\mathrm{CaCO}_{3}$ precipitation. Also, the distribution and morphology of the precipitated $\mathrm{CaCO}_{3}$ in an EICP process is often difficult to control, especially, under field conditions. In general, precipitated $\mathrm{CaCO}_{3}$ from the EICP process can appear in six different crystal forms (polymorphs) which include calcite, aragonite, vaterite, $\mathrm{CaCO}_{3}$ hexahydrate, $\mathrm{CaCO}_{3}$ monohydrate and amorphous $\mathrm{CaCO}_{3}$, in decreasing order of stability [1]. Rhombohedral calcite crystals exhibit well developed and distinct consolidation and these have been identified as the most desirable $\mathrm{CaCO}_{3}$ polymorph for geotechnical applications due to its thermodynamic stability $[19,114]$. The least thermodynamically stable polymorphs of $\mathrm{CaCO}_{3}$ appear during rapid precipitation at high supersaturation levels and these change rapidly into a more stable anhydrous phase. Almajed, Khodadadi Tirkolaei [19] stated that, rapid precipitation of $\mathrm{CaCO}_{3}$ in EICP, compared to MICP, can be disadvantageous because it can sometimes result in the formation of unstable vaterite and other amorphous $\mathrm{CaCO}_{3}$. The influence of urease enzyme activity on $\mathrm{CaCO}_{3}$ polymorphs in EICP was studied by Ahenkorah, Rahman [17] via SEM images using high-activity (40,150 U/g) and low-activity (3500 U/g) purified enzyme. The authors found that the low-activity enzyme produced anhedral calcite crystals while the high-activity enzyme produced mostly euhedral calcite crystals. The differences in the observed morphology may be attributed to the degree of purity of both enzymes, as also suggested by Khodadadi, Javadi [115].

It is well understood that the chemical reactions in EICP may be influenced by numerous factors including enzyme inhibitors, which cannot be captured via $\mathrm{CaCO}_{3}$ quantification in test-tubes, as used in previous studies $[19,20,106]$. Therefore, an effective bonding via soil improvement in EICP can be achieved by taking into account the kinetic mechanisms of the reaction.

\subsection{Erosion and Dust Control}

In addition to the improvement of soil strength, the precipitated $\mathrm{CaCO}_{3}$ in $\mathrm{EICP}$ can fill the voids within the soil matrix thereby reducing porosity and permeability [18,116-128]. Knorr [116] applied the EICP technique to control the impacts of water and wind erosion using different soil types such as Ottawa F60 sand, silty-sand and mine tailings. The results showed that EICP can be a potential technique to prevent erosion caused by both wind and runoff of surface water. Hamdan and Kavazanjian [129] tested the effectiveness of EICP in stabilising soils against fugitive dust emissions in a wind tunnel. In their experiment, different types of sand were prepared in a pan and sprayed in a series with an EICP solution. They concluded that the EICP technique gives a promising outcome for mitigating fugitive dust emissions.

Cuccurullo, Gallipoli [117] applied the EICP technique to mitigate the effects of water erosion on a silty clay. They found that EICP-treated samples exhibited a threefold improvement in terms of the mass of soil lost compared to untreated specimens. Many other researchers have evaluated the effectiveness of the EICP technique for dust control [118-121] and surface water erosion mitigation [122-125], and have found the results to be satisfactory.

\subsection{Removal of Heavy Metals}

Heavy metals and other contaminants generated as industrial by-products can lead to a significant impact on our environment. The use of conventional treatment methods to remove heavy metals from contaminated environments can be expensive and consumes high amounts of chemicals and energy. Therefore, EICP can be an environmentally friendly alternative for the removal of heavy metals and other waste contaminants.

Nam, Roh [130] applied the EICP technique to immobilize and remove heavy metals and metalloids in contaminated mine wastes. The results from their study indicated that the concentrations of $\mathrm{As}, \mathrm{Mn}, \mathrm{Zn}, \mathrm{Pb}, \mathrm{Cr}$ and $\mathrm{Cu}$ were reduced by 31.7\%, 65.8\%, 50.6\%, 51.6\%, 45.1\% and 49.7\%, respectively. Moghal, Lateef [99] and Moghal, Lateef [131] investigated the efficacy of the EICP method on adsorption and desorption of soils mixed with different 
combinations of heavy metals. Their results indicated that EICP could immobilize to a significant level the heavy metals in selected soils.

\section{Conclusions and Future Perspectives}

This paper reviewed the developments in the area of enzyme-catalysed reactions over the last century and their applications in the enzyme-induced carbonate precipitation (EICP) process. The major conclusions from this review are summarised as:

- The activity of the urease enzyme is largely controlled by the presence of a binuclear Ni complex active site in the $\beta$-sheet structure and the dynamic opening and closing of the mobile flap located adjacent to the active site.

- Studies on optimisation of the EICP process have often been conducted by using the discontinuous approach, which involves mixing the substrate and enzyme and measuring the product formed after a set period. However, this approach cannot easily capture the catalytic properties, such as the influence of urease activity and product inhibition on the enzyme-catalysed reaction. Therefore, the continuous enzyme kinetic assay, which involves mixing the enzyme with the substrate and continuously measuring the product formed or the dissociation of the substrate over time, should be considered in future studies.

- It is understood from this study that the reaction velocity of an enzyme catalysed reaction is mainly influenced by $\mathrm{pH}$, temperature and inhibitors (ammonium ion). A meta-analysis of data from a previous study indicate that $\mathrm{pH}$ and ammonium ions greatly affect $\mathrm{V}_{\max }$ compared to $\mathrm{K}_{\mathrm{m}}$, whereas $\mathrm{k}_{\text {cat }}$ was greatly influenced by temperature. A modified form of the Michaelis-Menten equation was proposed in this study, which can be used to capture the kinetic reaction in EICP under various conditions.

- The findings from this study indicate that ignoring the influence of product inhibition in an enzyme-catalysed reaction may result in a poor prediction of the kinetic parameters. Hence, various sources of urease inhibitors including amides and esters of phosphoric acid, thiols, hydroxamic acids, phosphinic and thiophosphinic acids, boric acid, phosphate, heavy metal ions, bismuth compounds, quinones and fluoride have been studied.

- Although the kinetic equations analysed and proposed in this study are useful for the EICP process, future studies on the influence of enzyme kinetic reactions in different soil environments are highly recommended. The development of kinetic models that capture the effects of using an enzyme from different plant sources should also be considered for future studies.

Author Contributions: Conceptualization, I.A. and M.M.R.; formal analysis, I.A., M.M.R. and M.R.K.; methodology, I.A., M.M.R. and M.R.K.; resources, M.M.R., M.R.K. and S.B.; validation, I.A., M.M.R., M.R.K. and C.S.; writing-original draft, I.A., M.M.R. and M.R.K.; writing-review and editing, M.M.R., M.R.K., S.B. and C.S. All authors have read and agreed to the published version of the manuscript.

Funding: This research received no external funding.

Institutional Review Board Statement: Not applicable.

Informed Consent Statement: Not applicable.

Data Availability Statement: No new data were created or analyzed in this study. Data sharing is not applicable to this article.

Conflicts of Interest: The authors declare no conflict of interest. 


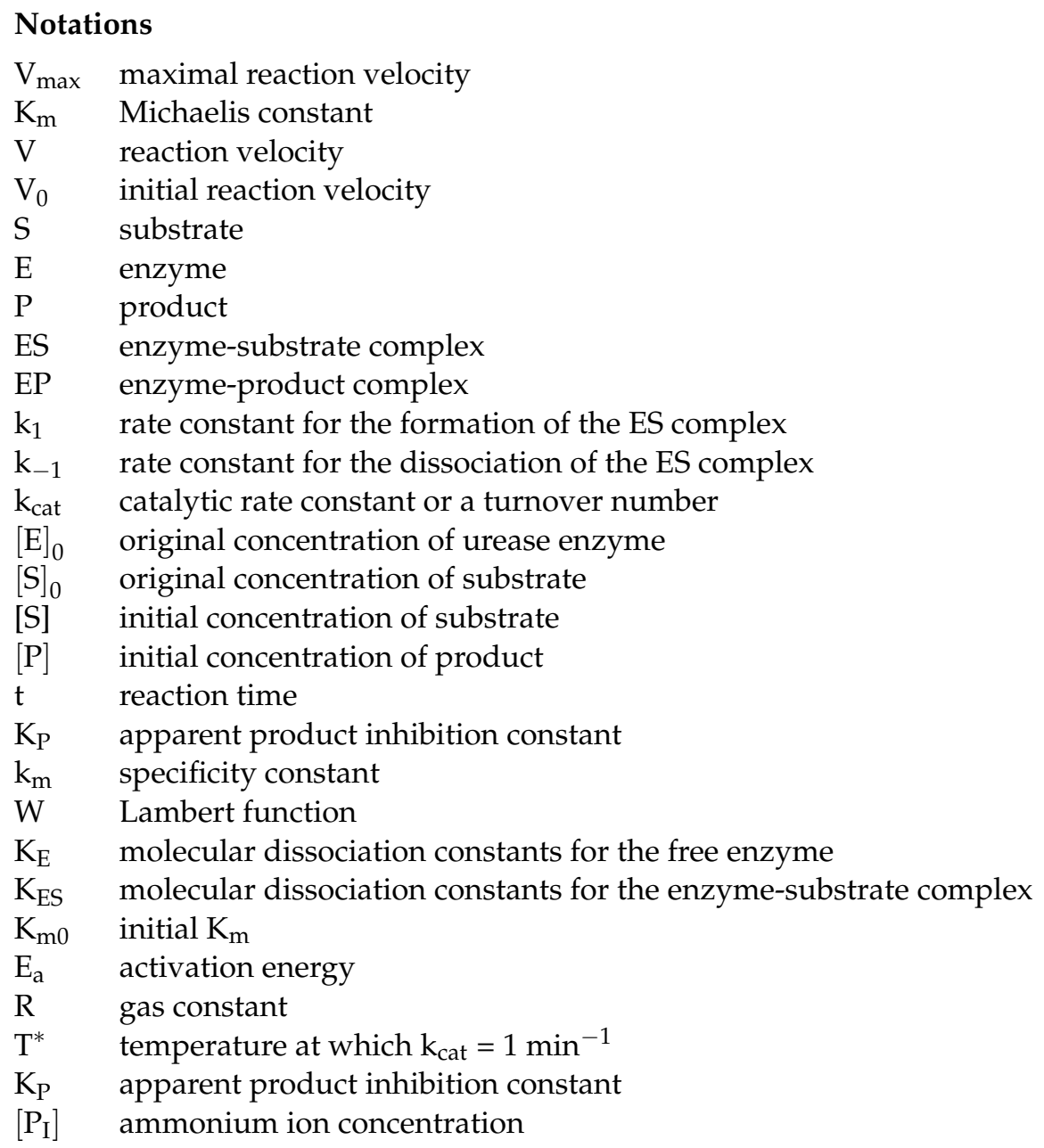

\section{References}

1. Krajewska, B. Urease-aided calcium carbonate mineralization for engineering applications: A review. J. Adv. Res. 2017, 13, 59-67. [CrossRef] [PubMed]

2. Putra, H.; Yasuhara, H.; Kinoshita, N. Applicability of natural zeolite for nh-forms removal in enzyme-mediated calcite precipitation technique. Geosciences 2017, 7, 61. [CrossRef]

3. Ahenkorah, I.; Rahman, M.M.; Karim, M.R.; Teasdale, P.R. A comparison of mechanical responses for microbial and enzymeinduced cemented sand. Géotechnique Lett. 2020, 10, 1-26. [CrossRef]

4. Neupane, D.; Yasuhara, H.; Kinoshita, N.; Ando, Y. Distribution of mineralized carbonate and its quantification method in enzyme mediated calcite precipitation technique. Soils Found. 2015, 55, 447-457. [CrossRef]

5. Hamdan, N.M. Applications of Enzyme Induced Carbonate Precipitation (Eicp) for Soil Improvement. Ph.D. Thesis, Arizona State University, Tempe, AZ, USA, 2015.

6. Dilrukshi, R.; Kawasaki, S. Effective use of plant-derived urease in the field of geoenvironmental. Geotech. Eng. J. Civ. Environ. Eng. 2016, 6, 2.

7. Suárez, D.; Díaz, N.; Merz, K.M. Ureases: Quantum chemical calculations on cluster models. J. Am. Chem. Soc. 2003, 125, 15324-15337. [CrossRef]

8. Zimmer, M. Are classical molecular mechanics calculations still useful in bioinorganic simulations? Coord. Chem. Rev. 2009, 253, 817-826. [CrossRef]

9. Smyj, R.P. A conformational analysis study of a nickel (ii) enzyme: Urease. J. Mol. Struct. THEOCHEM 1997, 391, 207-223. [CrossRef]

10. Michaelis, L.; Menten, M.L. Die kinetik der invertinwirkung. Biochem. Z 1913, 49, 333-369.

11. Krajewska, B. Ureases i. Functional, catalytic and kinetic properties: A review. J. Mol. Catal. B Enzym. 2009, 59, 9-21. [CrossRef]

12. Johnson, K.A. Fitting enzyme kinetic data with kintek global kinetic explorer. Methods Enzymol. 2009, 467, 601-626.

13. Krajewska, B. A combined temperature-ph study of urease kinetics. Assigning pka values to ionizable groups of the active site involved in the catalytic reaction. J. Mol. Catal. B Enzym. 2016, 124, 70-76. [CrossRef] 
14. Benini, S.; Rypniewski, W.R.; Wilson, K.S.; Miletti, S.; Ciurli, S.; Mangani, S. A new proposal for urease mechanism based on the crystal structures of the native and inhibited enzyme from bacillus pasteurii: Why urea hydrolysis costs two nickels. Structure 1999, 7, 205-216. [CrossRef]

15. Sheldon, R.A. Enzyme immobilization: The quest for optimum performance. Adv. Synth. Catal. 2007, 349, 1289-1307. [CrossRef]

16. Krajewska, B. Ureases. Ii. Properties and their customizing by enzyme immobilizations: A review. J. Mol. Catal. B Enzym. 2009, 59, 22-40. [CrossRef]

17. Ahenkorah, I.; Rahman, M.M.; Karim, M.R.; Teasdale, P.R. Optimization of Enzyme Induced Carbonate Precipitation (Eicp) as a Ground Improvement Technique; Geo-Congress 2020: Foundations, Soil Improvement, and Erosion; American Society of Civil Engineers: Reston, VA, USA, 2020; pp. 552-561.

18. Neupane, D.; Yasuhara, H.; Kinoshita, N.; Unno, T. Applicability of enzymatic calcium carbonate precipitation as a soilstrengthening technique. J. Geotech. Geoenviron. Eng. 2013, 139, 2201-2211. [CrossRef]

19. Almajed, A.; Khodadadi Tirkolaei, H.; Kavazanjian, E., Jr. Baseline investigation on enzyme-induced calcium carbonate precipitation. J. Geotech. Geoenviron. Eng. 2018, 144, 04018081. [CrossRef]

20. Putra, H.; Yasuhara, H.; Kinoshita, N.; Neupane, D. Optimization of Calcite Precipitation as a Soil Improvement Technique. In Proceedings of the 2nd Makassar International Conference on Civil Engineering, Makassar, Indonesia, 11-12 August 2015; pp. 11-12.

21. Carmona, J.P.; Oliveira, P.J.V.; Lemos, L.J. Biostabilization of a sandy soil using enzymatic calcium carbonate precipitation. Procedia Eng. 2016, 143, 1301-1308. [CrossRef]

22. Sumner, J.B. The isolation and crystallization of the enzyme urease preliminary paper. J. Biol. Chem. 1926, 69, 435-441. [CrossRef]

23. Mazzei, L.; Musiani, F.; Ciurli, S. The structure-based reaction mechanism of urease, a nickel dependent enzyme: Tale of a long debate. J. Biol. Inorg. Chem. 2020, 25, 829-845. [CrossRef]

24. Kafarski, P.; Talma, M. Recent advances in design of new urease inhibitors: A review. J. Adv. Res. 2018, 13, 101-112. [CrossRef] [PubMed]

25. Follmer, C. Insights into the role and structure of plant ureases. Phytochemistry 2008, 69, 18-28. [CrossRef] [PubMed]

26. Mobley, H.; Island, M.D.; Hausinger, R.P. Molecular biology of microbial ureases. Microbiol. Rev. 1995, 59, 451-480. [CrossRef]

27. Sirko, A.; Brodzik, R. Plant ureases: Roles and regulation. Acta Biochim. Pol. 2000, 47, 1189-1195. [CrossRef] [PubMed]

28. Das, N.; Kayastha, A.M.; Srivastava, P.K. Purification and characterization of urease from dehusked pigeonpea (cajanus cajan 1.) seeds. Phytochemistry 2002, 61, 513-521. [CrossRef]

29. Nam, I.-H.; Chon, C.-M.; Jung, K.-Y.; Choi, S.-G.; Choi, H.; Park, S.-S. Calcite precipitation by ureolytic plant (canavalia ensiformis) extracts as effective biomaterials. KSCE J. Civ. Eng. 2015, 19, 1620-1625. [CrossRef]

30. Takatsu, M.; Nadeeka, R.; Kawasaki, S. Development of biogrouting using plant-derived urease and calcium phosphate compound. In Proceedings of the 50th US Rock Mechanics/Geomechanics Symposium, Huston, TX, USA, 26-29 June 2016.

31. Balasubramanian, A.; Ponnuraj, K. Crystal structure of the first plant urease from jack bean: 83 years of journey from its first crystal to molecular structure. J. Mol. Biol. 2010, 400, 274-283. [CrossRef]

32. Kunduru, K.R.; Kutcherlapati, S.R.; Arunbabu, D.; Jana, T. Armored urease: Enzyme-bioconjugated poly (acrylamide) hydrogel as a storage and sensing platform. Methods Enzymol. 2017, 590, 143-167.

33. Jabri, E.; Carr, M.B.; Hausinger, R.P.; Karplus, P.A. The crystal structure of urease from klebsiella aerogenes. Science 1995, 268, 998-1004. [CrossRef] [PubMed]

34. Krajewska, B.; Zaborska, W. Jack bean urease: The effect of active-site binding inhibitors on the reactivity of enzyme thiol groups. Bioorg. Chem. 2007, 35, 355-365. [CrossRef]

35. Roberts, B.P.; Miller, B.R., III; Roitberg, A.E.; Merz, K.M., Jr. Wide-open flaps are key to urease activity. J. Am. Chem. Soc. 2012, 134, 9934-9937. [CrossRef]

36. Sharma, B.; Mandani, S.; Sarma, T.K. Biogenic growth of alloys and core-shell nanostructures using urease as a nanoreactor at ambient conditions. Sci. Rep. 2013, 3, 2601. [CrossRef]

37. Kucharski, E.S.; Cord-Ruwisch, R.; Whiffin, V.; Al-thawadi, S.M. Microbial Biocementation; Google Patents: San Francisco, CA, USA, 2012.

38. Kappaun, K.; Piovesan, A.R.; Carlini, C.R.; Ligabue-Braun, R. Ureases: Historical aspects, catalytic, and non-catalytic properties-A review. J. Adv. Res. 2018, 13, 3-17. [CrossRef]

39. Dixon, N.E.; Gazzola, C.; Blakeley, R.L.; Zerner, B. Jack bean urease (ec 3.5. 1.5). Metalloenzyme. Simple biological role for nickel. J. Am. Chem. Soc. 1975, 97, 4131-4133. [CrossRef] [PubMed]

40. Zimmer, M. Molecular mechanics evaluation of the proposed mechanisms for the degradation of urea by urease. J. Biomol. Struct. Dyn. 2000, 17, 787-797. [CrossRef]

41. Alberts, B.; Johnson, A.; Lewis, J.; Raff, M.; Roberts, K.; Walter, P. Molecular biology of the cell 4th edn (new york: Garland science). Ann. Bot. 2002, 91, 401.

42. Laidler, K.J. Theory of the transient phase in kinetics, with special reference to enzyme systems. Can. J. Chem. 1955, 33, 1614-1624. [CrossRef]

43. Hommes, F. The integrated michaelis-menten equation. Arch. Biochem. Biophys. 1962, 96, 28-31. [CrossRef]

44. Wong, J.T.-F. On the steady-state method of enzyme kinetics. J. Am. Chem. Soc. 1965, 87, 1788-1793. [CrossRef] 
45. Stayton, M.M.; Fromm, H.J. A computer analysis of the validity of the integrated michaelis-menten equation. J. Theor. Biol. 1979, 78, 309-323. [CrossRef]

46. Beal, S.L. On the solution to the michaelis-menten equation. J. Pharmacokinet. Biopharm. 1982, 10, 109-119. [CrossRef] [PubMed]

47. Schnell, S.; Mendoza, C. Closed form solution for time-dependent enzyme kinetics. J. Theor. Biol. 1997, 187, 207-212. [CrossRef]

48. Corless, R.M.; Gonnet, G.H.; Hare, D.E.; Jeffrey, D.J.; Knuth, D. Lambert's w function in maple. Maple Tech. Newsl. 1993, 9, 12-22.

49. Fritsch, F.N.; Shafer, R.; Crowley, W. Solution of the transcendental equation wew=x. Commun. ACM 1973, 16, 123-124. [CrossRef]

50. Tzafriri, A.R. Michaelis-menten kinetics at high enzyme concentrations. Bull. Math. Biol. 2003, 65, 1111-1129. [CrossRef]

51. Kuzmič, P. Dynafit-A software package for enzymology. Methods Enzymol. 2009, 467, 247-280.

52. Bevc, S.; Konc, J.; Stojan, J.; Hodošček, M.; Penca, M.; Praprotnik, M.; Janežič, D. Enzo: A web tool for derivation and evaluation of kinetic models of enzyme catalyzed reactions. PLoS ONE 2011, 6, e22265. [CrossRef]

53. Zavrel, M.; Kochanowski, K.; Spiess, A.C. Comparison of different approaches and computer programs for progress curve analysis of enzyme kinetics. Eng. Life Sci. 2010, 10, 191-200. [CrossRef]

54. Putra, H.; Yasuhara, H.; Kinoshita, N.; Hirata, A. Optimization of enzyme-mediated calcite precipitation as a soil-improvement technique: The effect of aragonite and gypsum on the mechanical properties of treated sand. Crystals 2017, 7, 59. [CrossRef]

55. Robinson, P.K. Enzymes: Principles and biotechnological applications. Essays Biochem. 2015, 59, 1-41. [CrossRef]

56. Segel, I. Enzyme Kinetics; John Wiley \& Sons: New York, NY, USA, 1975.

57. Lineweaver, H.; Burk, D. The determination of enzyme dissociation constants. J. Am. Chem. Soc. 1934, 56, 658-666. [CrossRef]

58. Hanes, C.S. Studies on plant amylasesthe effect of starch concentration upon the velocity of hydrolysis by the amylase of germinated barley. Biochem. J. 1932, 26, 1406-1421. [CrossRef] [PubMed]

59. Haldane, J. Graphical methods in enzyme chemistry. Nature 1957, 179, 832. [CrossRef]

60. Eadie, G.S. The inhibition of cholinesterase by physostigmine and prostigmine. J. Biol. Chem. 1942, 146, 85-93. [CrossRef]

61. Liao, F.; Zhu, X.-Y.; Wang, Y.-M.; Zuo, Y.-P. The comparison of the estimation of enzyme kinetic parameters by fitting reaction curve to the integrated michaelis-menten rate equations of different predictor variables. J. Biochem. Bioph. Methods 2005, 62, 13-24. [CrossRef]

62. Atkins, G.L.; Nimmo, I.A. The reliability of michaelis constants and maximum velocities estimated by using the integrated michaelis-menten equation. Biochem. J. 1973, 135, 779-784. [CrossRef]

63. Orsi, B.A. Kinetic analysis of progress curves. Methods Enzymol. 1979, 63, 159-183. [PubMed]

64. Newman, P.F.; Atkins, G.L.; Nimmo, I.A. The effect of systematic error on the accuracy of michaelis constants and maximum velocities estimated by using the integrated michaelis-menten equation. Biochem. J. 1974, 143, 779-781. [CrossRef]

65. Johnson, K.A.; Goody, R.S. The original michaelis constant: Translation of the 1913 michaelis-menten paper. Biochemistry 2011, 50, 8264-8269. [CrossRef]

66. Goličnik, M. The integrated michaelis-menten rate equation: Déjà vu or vu jàdé? J. Enzym. Inhib. Med. Chem. 2013, 28, 879-893. [CrossRef]

67. Wen, K.J.; Li, Y.; Amini, F.; Li, L. Impact of bacteria and urease concentration on precipitation kinetics and crystal morphology of calcium carbonate. Acta Geotech. 2020, 15, 17-27. [CrossRef]

68. Cesareo, S.D.; Langton, S.R. Kinetic properties of helicobacter pylori urease compared with jack bean urease. FEMS Microbiol. Lett. 1992, 99, 15-21. [CrossRef]

69. Dixon, N.E.; Riddles, P.W.; Gazzola, C.; Blakeley, R.L.; Zerner, B. Jack bean urease (ec 3.5. 1.5). V. On the mechanism of action of urease on urea, formamide, acetamide, n-methylurea, and related compounds. Can. J. Biochem. 1980, 58, 1335-1344. [CrossRef]

70. Tipton, K.F.; Dixon, H.B. Effects of ph on enzymes. Methods Enzymol. 1979, 63, 183-234. [PubMed]

71. Fidaleo, M.; Lavecchia, R. Kinetic study of enzymatic urea hydrolysis in the ph range 4-9. Chem. Biochem. Eng. Q. 2003, 17, 311-318.

72. Krajewska, B.; van Eldik, R.; Brindell, M. Temperature-and pressure-dependent stopped-flow kinetic studies of jack bean urease. Implications for the catalytic mechanism. J. Biol. Inorg. Chem. 2012, 17, 1123-1134. [CrossRef] [PubMed]

73. Barth, A.; Michel, H. A contribution on the mechanism of the enzymatic cleavage of urea. Biochem. Physiol. Pflanzen 1972, 163, 103-109.

74. Krajewska, B.; Ciurli, S. Jack bean (canavalia ensiformis) urease. Probing acid-base groups of the active site by ph variation. Plant Physiol. Biochem. 2005, 43, 651-658. [CrossRef] [PubMed]

75. Martins, M.B.F.; Cruz, M.E.M.; Cabral, J.M.; Kennedy, J.F. Urease immobilization on an alkylamine derivative of titanium (iv)-porous silica: Kinetics and operational stability. J. Chem. Technol. Biotechnol. 1987, 39, 201-213. [CrossRef]

76. Huang, T.C.; Chen, D.H. Kinetic study of urease-catalysed urea hydrolysis. J. Chem. Technol. Biotechnol. 1991, 52, 433-444. [CrossRef]

77. Putra, H.; Yasuhara, H.; Kinoshita, N.; Hirata, A. Application of magnesium to improve uniform distribution of precipitated minerals in 1-m column specimens. Geomech. Eng. 2017, 12, 803-813. [CrossRef]

78. Putra, H.; Yasuhara, H.; Kinoshita, N.; Neupane, D.; Lu, C. Effect of magnesium as substitute material in enzyme-mediated calcite precipitation for soil-improvement technique. Front. Bioeng. Biotechnol. 2016, 4, 37. [CrossRef]

79. Jada, A.; Jradi, K. Role of polyelectrolytes in crystallogenesis of calcium carbonate. In Macromolecular Symposia; Wiley Online Library: Weinheim, Germany, 2006; pp. 147-151. 
80. Yashchenok, A.; Parakhonskiy, B.; Donatan, S.; Kohler, D.; Skirtach, A.; Möhwald, H. Polyelectrolyte multilayer microcapsules templated on spherical, elliptical and square calcium carbonate particles. J. Mater. Chem. B 2013, 1, 1223-1228. [CrossRef]

81. Williams, F.V.; Ruehrwein, R.A. Effect of polyelectrolytes on the precipitation of calcium carbonate. J. Am. Chem. Soc. 1957, 79, 4898-4900. [CrossRef]

82. Putra, H.; Yasuhara, H.; Kinoshita, N. Optimum condition for the application of enzyme-mediated calcite precipitation technique as soil improvement technique. Int. J. Adv. Sci. Eng. Inf. Technol. 2017, 7, 2145-2151. [CrossRef]

83. Hoare, J.; Laidler, K. The molecular kinetics of the urea-urease system. Ii. The inhibition by products1. J. Am. Chem. Soc. 1950, 72, 2487-2489. [CrossRef]

84. Leszko, M.; Zaborska, W.; Krajewska, B. Urease-catalyzed hydrolysis of urea differential vs. Integration kinetic methods. Bull. Pol. Acad. Sci.-Chem. 1997, 45, 129-138.

85. Van Slyke, D.D.; Cullen, G.E. The mode of action of urease and of enzymes in general. J. Biol. Chem. 1914, 19, 141-180. [CrossRef]

86. Schäfer, U.K.; Kaltwasser, H. Urease from staphylococcus saprophyticus: Purification, characterization and comparison to staphylococcus xylosus urease. Arch. Microbiol. 1994, 161, 393-399.

87. Pham, V.P.; Nakano, A.; Van Der Star, W.R.; Heimovaara, T.J.; Van Paassen, L.A. Applying micp by denitrification in soils: A process analysis. Environ. Geotech. 2016, 5, 79-93. [CrossRef]

88. Contreras-Rodriguez, A.; Quiroz-Limon, J.; Martins, A.M.; Peralta, H.; Avila-Calderon, E.; Sriranganathan, N.; Boyle, S.M.; Lopez-Merino, A. Enzymatic, immunological and phylogenetic characterization of brucella suis urease. BMC Microbiol. 2008, 8, 121. [CrossRef]

89. Todd, M.J.; Hausinger, R. Competitive inhibitors of klebsiella aerogenes urease. Mechanisms of interaction with the nickel active site. J. Biol. Chem. 1989, 264, 15835-15842. [CrossRef]

90. Benini, S.; Rypniewski, W.R.; Wilson, K.S.; Miletti, S.; Ciurli, S.; Mangani, S. The complex of bacillus pasteurii urease with acetohydroxamate anion from x-ray data at 1.55 å resolution. JBIC J. Biol. Inorg. Chem. 2000, 5, 110-118. [CrossRef] [PubMed]

91. Krajewska, B.; Brindell, M. Thermodynamic study of competitive inhibitors' binding to urease. J. Therm. Anal. Calorim. 2016, 123, 2427-2439. [CrossRef]

92. Zhang, L.; Mulrooney, S.B.; Leung, A.F.; Zeng, Y.; Ko, B.B.; Hausinger, R.P.; Sun, H. Inhibition of urease by bismuth (iii): Implications for the mechanism of action of bismuth drugs. Biometals 2006, 19, 503-511. [CrossRef]

93. Krajewska, B.; Zaborska, W. Double mode of inhibition-inducing interactions of 1, 4-naphthoquinone with urease: Arylation versus oxidation of enzyme thiols. Biorg. Med. Chem. 2007, 15, 4144-4151. [CrossRef]

94. Zaborska, W.; Krajewska, B.; Kot, M.; Karcz, W. Quinone-induced inhibition of urease: Elucidation of its mechanisms by probing thiol groups of the enzyme. Bioorg. Chem. 2007, 35, 233-242. [CrossRef]

95. Mazzei, L.; Cianci, M.; Musiani, F.; Ciurli, S. Inactivation of urease by 1, 4-benzoquinone: Chemistry at the protein surface. Dalton Trans. 2016, 45, 5455-5459. [CrossRef]

96. Kot, M.; Zaborska, W. Inhibition of jack bean urease by tetrachloro-o-benzoquinone and tetrachloro-p-benzoquinone. J. Enzym. Inhib. Med. Chem. 2006, 21, 537-542. [CrossRef]

97. Krajewska, B.; Zaborska, W.a.; Leszko, M. Inhibition of chitosan-immobilized urease by slow-binding inhibitors: Ni2+, f- and acetohydroxamic acid. J. Mol. Catal. B Enzym. 2001, 14, 101-109. [CrossRef]

98. Krajewska, B. Mono-(ag, hg) and di-(cu, hg) valent metal ions effects on the activity of jack bean urease. Probing the modes of metal binding to the enzyme. J. Enzym. Inhib. Med. Chem. 2008, 23, 535-542. [CrossRef]

99. Moghal, A.A.B.; Lateef, M.A.; Mohammed, S.A.S.; Ahmad, M.; Usman, A.R.; Almajed, A. Heavy metal immobilization studies and enhancement in geotechnical properties of cohesive soils by eicp technique. Appl. Sci. 2020, 10, 7568. [CrossRef]

100. Benini, S.; Cianci, M.; Mazzei, L.; Ciurli, S. Fluoride inhibition of sporosarcina pasteurii urease: Structure and thermodynamics. JBIC J. Biol. Inorg. Chem. 2014, 19, 1243-1261. [CrossRef]

101. Krajewska, B.; Zaborska, W.; Leszko, M.; Brzózka, Z. Inhibition of jack bean urease by a mixture of boric acid and phosphate buffer ph 6.96. Pol. J. Chem. 1999, 73, 359-366.

102. Reddy, M.S. Biomineralization of calcium carbonates and their engineered applications: A review. Front. Microbiol. $2013,4,314$.

103. McCarty, G.; Bremner, J.; Lee, J. Inhibition of plant and microbial ureases by phosphoroamides. Plant Soil 1990, 127, 269-283. [CrossRef]

104. Dixon, N.E.; Hinds, J.A.; Fihelly, A.K.; Gazzola, C.; Winzor, D.J.; Blakeley, R.L.; Zerner, B. Jack bean urease (ec 3.5. 1.5). Iv. The molecular size and the mechanism of inhibition by hydroxamic acids. Spectrophotometric titration of enzymes with reversible inhibitors. Can. J. Biochem. 1980, 58, 1323-1334. [CrossRef] [PubMed]

105. Krajewska, B. Urease immobilized on chitosan membrane. Inactivation by heavy metal ions. J. Chem. Technol. Biotechnol. 1991, 52, 157-162. [CrossRef]

106. Yasuhara, H.; Neupane, D.; Hayashi, K.; Okamura, M. Experiments and predictions of physical properties of sand cemented by enzymatically-induced carbonate precipitation. Soils Found. 2012, 52, 539-549. [CrossRef]

107. Kavazanjian, E.; Hamdan, N. Enzyme induced carbonate precipitation (eicp) columns for ground improvement. In IFCEE 2015; American Society of Civil Engineers: Reston, VA, USA, 2015; pp. 2252-2261.

108. Rahman, M.M.; Hora, R.N.; Ahenkorah, I.; Beecham, S.; Karim, M.R.; Iqbal, A. State-of-the-Art Review of Microbial-Induced Calcite Precipitation and Its Sustainability in Engineering Applications. Sustainability 2020, 12, 6281. [CrossRef] 
109. Dakhane, A.; Das, S.; Hansen, H.; O’Donnell, S.; Hanoon, F.; Rushton, A.; Perla, C.; Neithalath, N. Crack healing in cementitious mortars using enzyme-induced carbonate precipitation: Quantification based on fracture response. J. Mater. Civ. Eng. 2018, 30, 04018035. [CrossRef]

110. Hamdan, N.; Kavazanjian, E., Jr.; O'Donnell, S. Carbonate Cementation via Plant Derived Urease. In Proceedings of the 18th International Conference on Soil Mechanics and Geotechnical Engineering, Paris, France, 2-6 September 2013.

111. Dilrukshi, R.; Nakashima, K.; Kawasaki, S. Soil improvement using plant-derived urease-induced calcium carbonate precipitation. Soils Found. 2018, 58, 894-910. [CrossRef]

112. Simatupang, M.; Okamura, M. Liquefaction resistance of sand remediated with carbonate precipitation at different degrees of saturation during curing. Soils Found. 2017, 57, 619-631. [CrossRef]

113. Putra, H.; Yasuhara, H.; Kinoshita, N.; Fauzan, M. Promoting precipitation technique using bio-chemical grouting for soil liquefaction prevention. Civil Eng. Dimens. 2020, 22, 1-5. [CrossRef]

114. Dilrukshia, R.; Kawasakib, S. Plant-derived urease induced sand cementation used in geotechnical engineering applications. In Proceedings of the International Conference on Geomechanics, Geo-Energy and Geo-Resources, Melbourne, Australia, 28-29 September 2016.

115. Khodadadi, T.H.; Javadi, N.; Krishnan, V.; Hamdan, N.; Kavazanjian, E.J. Crude urease extract for biocementation. J. Mater. Civil Eng. 2020, 32, 04020374. [CrossRef]

116. Knorr, B. Enzyme-Induced Carbonate Precipitation for the Mitigation of Fugitive Dust. Ph.D. Thesis, Arizona State University, Tempe, AZ, USA, 2014.

117. Cuccurullo, A.; Gallipoli, D.; Bruno, A.W.; Augarde, C.; Hughes, P.; La Borderie, C. Soil stabilization against water erosion via calcite precipitation by plant-derived urease. In Proceedings of the National Conference of the Researchers of Geotechnical Engineering, Lecco, Italy, 3-5 July 2019; pp. 753-762.

118. Bang, S.C.; Min, S.H.; Bang, S.S. Kgs awards lectures: Application of microbiologically induced soil stabilization technique for dust suppression. Int. J. Geo-Eng. 2011, 3, 27-37.

119. Bang, S.S.; Bang, S.; Frutiger, S.; Nehl, L.M.; Comes, B.L. Application of novel biological technique in dust suppression. In Proceedings of the 88th Transportation Research Board Annual Meeting, Washington, DC, USA, 11-15 January 2009.

120. Lo, C.-Y.; Tirkolaei, H.K.; Hua, M.; De Rosa, I.M.; Carlson, L.; Kavazanjian, E., Jr.; He, X. Durable and ductile double-network material for dust control. Geoderma 2020, 361, 114090. [CrossRef]

121. Woolley, M.A.; Van Paassen, L.; Kavazanjian, E., Jr. Impact on surface hydraulic conductivity of eicp treatment for fugitive dust mitigation. In Geo-Congress 2020: Biogeotechnics; American Society of Civil Engineers: Reston, VA, USA, 2020; pp. 132-140.

122. Almajed, A.; Lemboye, K.; Arab, M.G.; Alnuaim, A. Mitigating wind erosion of sand using biopolymer-assisted eicp technique. Soils Found. 2020, 60, 356-371. [CrossRef]

123. Liu, K.-W.; Jiang, N.-J.; Qin, J.-D.; Wang, Y.-J.; Tang, C.-S.; Han, X.-L. An experimental study of mitigating coastal sand dune erosion by microbial-and enzymatic-induced carbonate precipitation. Acta Geotech. 2021, 16, 467-480. [CrossRef]

124. Miao, L.; Wu, L.; Sun, X. Enzyme-catalysed mineralisation experiment study to solidify desert sands. Sci. Rep. 2020, 10, 1-12. [CrossRef] [PubMed]

125. Ossai, R.; Rivera, L.; Bandini, P. Experimental study to determine an eicp application method feasible for field treatment for soil erosion control. In Geo-Congress 2020: Biogeotechnics; American Society of Civil Engineers: Reston, VA, USA, 2020 ; pp. $205-213$.

126. Nemati, M.; Greene, E.; Voordouw, G. Permeability profile modification using bacterially formed calcium carbonate: Comparison with enzymic option. Process Biochem. 2005, 40, 925-933. [CrossRef]

127. Nemati, M.; Voordouw, G. Modification of porous media permeability, using calcium carbonate produced enzymatically in situ. Enzym. Microb. Technol. 2003, 33, 635-642. [CrossRef]

128. Song, J.Y.; Sim, Y.; Jang, J.; Hong, W.T.; Yun, T.S. Near-surface soil stabilization by enzyme-induced carbonate precipitation for fugitive dust suppression. Acta Geotech. 2020, 15, 1967-1980. [CrossRef]

129. Hamdan, N.; Kavazanjian, E. Enzyme-induced carbonate mineral precipitation for fugitive dust control. Geotechnique 2016, 66, 546-555. [CrossRef]

130. Nam, I.-H.; Roh, S.-B.; Park, M.-J.; Chon, C.-M.; Kim, J.-G.; Jeong, S.-W.; Song, H.; Yoon, M.-H. Immobilization of heavy metal contaminated mine wastes using canavalia ensiformis extract. Catena 2015, 136, 53-58. [CrossRef]

131. Moghal, B.A.A.; Lateef, M.A.; Mohammed, S.A.S.; Lemboye, K.K.; Chittoori, B.C.S.; Almajed, A. Efficacy of enzymatically induced calcium carbonate precipitation in the retention of heavy metal ions. Sustainability 2020, 12, 7019. [CrossRef] 